\title{
Impacts of COVID-19 on Air Quality in India
}

\section{Aerosol and Air Quality Research}

Special Issue:

Special Issue on COVID-19 Aerosol Drivers, Impacts and Mitigation (XII)

\author{
Ram Lal Verma ${ }^{1 *}$, Jatinder Singh Kamyotra² \\ ${ }^{1}$ Regional Resource Centre for Asia and the Pacific, Asian Institute of Technology, Pathum Thani \\ -12120 , Thailand \\ ${ }^{2}$ Central Pollution Control Board, Delhi -110058 , India
}

\section{ABSTRACT}

The COVID-19 pandemic spread all over the world in early 2020. India imposed a nationwide lockdown on March 25, 2020, for more than a month to contain the COVID-19 infection. During the nationwide lockdown, transport, industries, and commercial activities were suspended, except for essential services. We made a detailed analysis of the impacts of COVID-19 on air quality in India by using the data from more than 200 Continuous Ambient Air Quality Monitoring Stations (CAAQMS) and reported a change in the National Air Quality Index (NAQI), spatial distribution and concentration levels of $\mathrm{PM}_{10}, \mathrm{PM}_{2.5}, \mathrm{CO}, \mathrm{NO}_{2}, \mathrm{SO}_{2}$, and $\mathrm{O}_{3}$ from January to April 2020 nationwide and in five major cities, namely, Delhi, Mumbai, Kolkata, Chennai, and Hyderabad. We defined the period between February 25 to March 24, 2020, as 'before lockdown' and March 25 to April 30, 2020, as 'during lockdown'. The NAQI and satellite visual maps of $\mathrm{AOD}, \mathrm{NO}_{2}, \mathrm{CO}$, and $\mathrm{SO}_{2}$ from January to April 2020 showed a significant decrease in air pollution levels in India. The average concentration levels of $\mathrm{PM}_{10}, \mathrm{PM}_{2.5}, \mathrm{CO}, \mathrm{NO}_{2}$, and $\mathrm{SO}_{2}$ have decreased nationwide by 33, 34, 21, 47 , and $21 \%$, respectively, during the nationwide lockdown compared to their concentration levels before the lockdown. While comparing their concentration levels of the nationwide lockdown period with those observed in April 2019 at the same CAAQMS, it was found that the nationwide average concentration levels of $\mathrm{PM}_{10}, \mathrm{PM}_{2.5}, \mathrm{CO}, \mathrm{NO}_{2}$, and $\mathrm{SO}_{2}$ were decreased by 53 , $45,27,54$, and $35 \%$, respectively. The trends of decreasing air pollutants during the lockdown in five major cities were almost the same as nationwide. The concentration levels of $\mathrm{O}_{3}$ have shown an increasing trend from January-April 2020 including during the nationwide lockdown. The COVID-19 has provided a rare opportunity for India for the collection of air pollution baseline data which could be useful in the formulation of air pollution reduction policies in the future.

Keywords: Air quality, Lockdown, COVID-19, Air quality index, Particulate matters

\section{INTRODUCTION}

India is facing serious air pollution problems. The air quality in most Indian cities has been deteriorating over the past many years (WHO, 2016; Bernard and Kazmin, 2018; Chowdhury et al, 2019; HEl, 2019; Mishra, 2019). The emissions of air pollutants from anthropogenic sources, such as transport, industry, power generation, construction, residential, and commercial activities have been increasing significantly during the past many years (Guttikunda et al., 2014; Kurokawa and Ohara, 2020). Open burning of municipal waste and agricultural residuals are adding extra emission burden of air pollutants in the region which significantly deteriorates air pollution problems, especially during winter when stagnant meteorology promotes accumulation of air pollutants in the atmosphere (Badarinath et al., 2009; Rastogi et al., 2016; Kumari et al., 2017; Liu et al., 2018; Bray et al., 2019; Sawlani et al., 2019). Increasing air pollution in India is significantly impacting air quality, increasing disease burdens, and incurring economic loss (Bhome, 2012; Rizwan et al., 2013; Bunett et al., 2018; Gordon et al., 2019; Reddy and Roberts, 2019).

The Severe Acute Respiratory Syndrome Coronavirus 2 (SARS-CoV-2) or commonly known as coronavirus disease 2019 (COVID-19) pandemic, emerged from the city of Wuhan, China, in December 2019, spread around the world in early 2020. Many countries imposed the lockdown 
in the cities, as well as, nationwide to minimize transmission of the COVID-19 infection. In the lockdown, commercial activities including transport, industries, and public gathering places were closed. As a result, the emissions of air pollutants were significantly decreased in many parts of the world (He et al., 2020; Patel and Stevens, 2020; Sulaman et al., 2020). For example, the total nitrogen dioxide $\left(\mathrm{NO}_{2}\right)$ column was reduced by about 40 percent $(\%)$ over the Chinese cities and 20-38\% over Western Europe (Bauwens et al., 2020). Sicard et al. (2020) reported a reduction in oxides of nitrogen $\left(\mathrm{NO}_{\mathrm{x}}\right)$ and particulate matters $(\mathrm{PM})$ by about $56 \%$ and $42 \%$, respectively, in Chinese cities. In the United States and Spain, a decrease in $\mathrm{NO}_{2}$ concentrations by $25.5 \%$ and 50-62\% were observed, respectively, (Berman and Ebisu, 2020; Baldasano, 2020).

India imposed a nationwide lockdown from March 25, 2020, onward for a few months to minimize the spread of the COVID-19 infection. During the lockdown, all transport services (road, airplane, and railway), schools, colleges, industrial operations, hotels, restaurants, shopping malls, markets were suspended, except for essential services (CPCB, 2020). The real-time National Air Quality Index (NAQI) published by the Central Pollution Control Board (CPCB, https://app.cpcbccr.com/AQI_India/) and CPCB's preliminary report on the NAQI suggested that the air pollution in India has been substantially decreased during the nationwide lockdown. This encouraged us to study in detail the impacts of the COVID-19 on air quality in India.

Several studies have been published on the impacts of the COVID-19 on air pollution level in India (Jain and Sharma, 2020; Kumar, 2020; Kumari and Toshniwal, 2020; Majumdar, 2020; Mahato et al., 2020; Sharma et al., 2020; Shehzad et al., 2020; Singh and Chauhan, 2020). However, most of the studies have reported measurements of air pollution in metro cities and urban regions. In this article, we reported the nationwide air pollution measurements, using the data from more than 200 Continuous Ambient Air Quality Monitoring Stations (CAAQMS) located all over the country, from January to April 2020, the trends in the change in NAQI in Indian states, the spatial distribution of concentrations of Aerosol Optical Depth (AOD) and Carbon Monoxide (CO), $\mathrm{NO}_{2}$, Sulfur Dioxide $\left(\mathrm{SO}_{2}\right)$, and Ozone $\left(\mathrm{O}_{3}\right)$ using the satellite visual maps, and made a comprehensive statistical analysis of the change in the concentrations of $\mathrm{PM}$ (both $\mathrm{PM}_{10}, \mathrm{PM}_{2.5}$ ), $\mathrm{CO}, \mathrm{NO}_{2}, \mathrm{SO}_{2}$, and $\mathrm{O}_{3}$ at nationwide and in major Indian cities, namely, Delhi, Mumbai, Kolkata, Chennai, and Hyderabad. For a better understanding of the impacts of the nationwide lockdown on the air pollution level, we defined, the period from February 25, 2020, to March 24, 2020, as "before lockdown" and from March 25, 2020, to April 30, 2020, as "during lockdown". We compared time-series and average concentrations of key air pollutants observed from January to April 2020 with those observed from January to April 2019.

\section{DATA COLLECTION}

\subsection{Air Pollutants}

India operates a network of 231 CAAQMS located in various parts of the country. Fig. 1 shows a spatial distribution of the CAAQMS network in India, blue dots are the location of each CAAQMS. These CAAQMS are operated by CPCB, State Pollution Control Boards (SPCBs), Delhi Pollution Control Committee (DPCC), and Indian Meteorological Department (IMD). Air pollution data from these CAAQMS acquired at CPCB. For the present study, we downloaded 24-hr averaged data from the CPCB website (https://app.cpcbccr.com/ccr/\#/caaqm-dashboard-all/caaqmlanding/data) for $\mathrm{PM}_{10}, \mathrm{PM}_{2.5}, \mathrm{CO}, \mathrm{NO}_{2}, \mathrm{SO}_{2}$, and $\mathrm{O}_{3}$ for January to April 2019 and January to April 2020. The data from January to April 2019 has been used only for comparison of temporal variations in the concentration levels of air pollutants for 2019 and 2020, while data observed in April 2019 included in statistical analysis for comparison of concentration levels of air pollutants that observed during the nationwide lockdown. We would like to clarify that quality control of data was beyond our reach since these CAAQMS are operated by different organizations and there is no information available on data quality control. However, we assumed that data quality control has been performed by the respective CAAQMS operators.

\subsection{National Air Quality Index}

CPCB published a real-time NAQI of 231 CAAQMS (https://app.cpcbccr.com/AQI_India/). NAQI is calculated by a weighted average of 8 criteria pollutants, namely, $\mathrm{PM}_{10}, \mathrm{PM}_{2.5}, \mathrm{SO}_{2}, \mathrm{NO}_{2}, \mathrm{CO}$, 


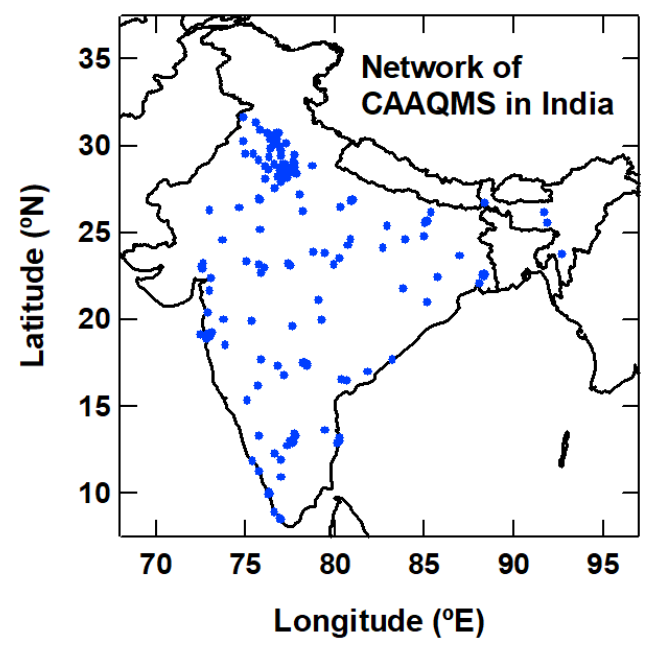

Fig. 1. A network of Continuous Ambient Air Quality Monitoring Stations (CAAQMS) in India. Blue dots are the geographic location (latitude and longitude) of each CAAQMS.

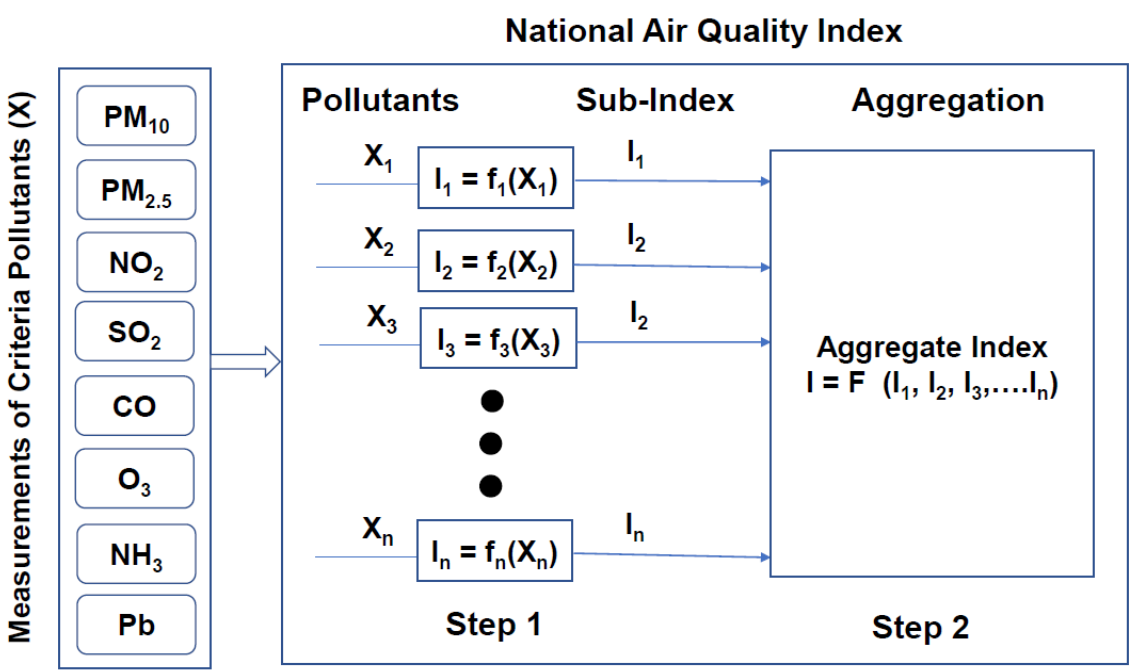

Fig. 2. A flow chart of the systematic scheme used by Quality Index (NAQI) from measurements of 8 criteria pollutants (CPCB, 2014).

$\mathrm{O}_{3}, \mathrm{NH}_{3}$, and Lead $(\mathrm{Pb})$ into a single value matrix. The basic scheme used by $C P C B$ for the calculation of NAQI is summarized in Fig. 2. Briefly, NAQI has been calculated in 2 steps. In step 1 , the sub-index of each criteria pollutant was calculated, and then in step 2, all sub-indexes were aggregated to a single index. Details of equations used for the calculation of NAQI have been discussed in the Report on National Air Quality Index (CPCB, 2014). For the present study, 24hour averaged NAQI data was downloaded from the CPCB website from January to April 2020 from the CAAQMS, shown in Fig. 1. If the number of CAAQMS in a city is more than one, one 24hour averaged NAQI value from all CAAQMS has been published for that city. Also, not all CAAQMS are operated all the time.

\subsection{Satellite Visual Maps}

Time-averaged visual maps of AOD (AOD at $550 \mathrm{~nm}$, daily 1 degree, MODIS-Aqua MYDO8_D3 v6.1), $\mathrm{NO}_{2}$ total column (1/cm², $30 \%$ cloud screened, daily 0.25 degree, OMI OMNO2d v003), CO surface concentration (ppbv, monthly $0.5 \times 0.625$ degree, MERRA-2 Model M2TMNXCHM v5.12.4), $\mathrm{SO}_{2}$ surface mass concentration ( $\mathrm{kg} \mathrm{m}^{-3}$, monthly $0.5 \times 0.625$ degree, MERRA-2 Model M2TMNXAER v5.12.4), $\mathrm{O}_{3}$ (Mole Fraction in Air, AIRS-only, daily 1 degree, @700 hPa, AIRS3STD v006), and Incoming Shortwave Flux ( $\mathrm{W} \mathrm{m}^{-2}$, MERRA-2 Model M2T1NXRAD v5.12.4, $0.5 \times 0.625$ deg.) were 
plotted online on NASA's GIOVANNI website (https://giovanni.gsfc.nasa.gov/giovanni/) from January to April 2020. The geographical domain chosen for satellite visual maps of India was $8 \mathrm{~N}^{\circ}-$ $35.5 \mathrm{~N}^{\circ}$ and $68 \mathrm{E}^{\circ}-97 \mathrm{E}^{\circ}$.

\section{RESULT AND DISCUSSION}

\subsection{NAQI}

Air Quality Index is an effective tool to communicate the status of air quality to the public in a single value matrix with its possible impacts on human health and the environment. Fig. 3(a) shows the visual maps of the state-wise spatial distribution of monthly averaged NAQI from January to April 2020. The value of NAQI for each state was calculated by averaging the daily NAQI values of all the CAAQMS located in the state and then it was further averaged to a single value for the state for each month. The average values of NAQI used in Fig. 3(a) for each state have been plotted separately in Fig. 3(b). In Fig. 3(a), the color filled in the states indicates the status of the air quality of the respective states on the NAQI color scale. CPCB categorized the NAQI color scale into six categories with value range and status, as follows: Green (0-50) - Good; Light green (51-100) - Satisfactory; Yellow (101-200) - Moderate; Orange (201-300) - Poor; Red (301-400) - Very poor, and Dark red (401-500) - Severe (https://cpcb.nic.in/national-air-qualityindex/). In Fig. 3(a), some states have been shown with grey color because no NAQI data was available for these states.

The state-wise spatial distribution (Fig. 3(a)) and state-wise NAQI (Fig. 3(b)) shows a visible trend in the improvement in air quality status (from bad to good) in each state from January to April 2020. In January and February 2020, the observed air quality status with NAQI range between 201-300 in the states of Bihar, Delhi, Uttar Pradesh, Odisha (not in February), and Assam was categorized as poor. Whereas, during the same months, the air quality status with NAQI range between 101-200 in the states of Odisha, Haryana, Jharkhand, West Bengal, Madhya Pradesh, Rajasthan, Maharashtra, Gujrat, Kerala, and Punjab was categorized as moderate (Fig. 3(b)). While in the rest of the states, namely, Telangana, Chandigarh, Andhra Pradesh, Tamil Nadu, Meghalaya, and Mizoram, the NAQI range was between $50-100$, and the air quality status was categorized as satisfactory in January and February 2020 (Fig. 3(b)). In India, the meteorological conditions improved from March onward with increasing surface temperature and vertical mixing which disperse the polluted air. In March 2020, the air quality status in the states of Bihar, Delhi, Uttar Pradesh, Assam, Odisha, Jharkhand, West Bengal, Rajasthan, Maharashtra, and Gujrat was moderate with NAQI ranging between 101 to 200, while in the states of Kerala, Punjab, Karnataka, Telangana, Chandigarh, Andhra Pradesh, Tamil Nadu, Madhya Pradesh, Haryana, Meghalaya, and Mizoram, the air quality status was good or satisfactory, with NAQI ranging in between 0 to 100 (Fig. 3(b)). In April 2020, which was also the nationwide lockdown period, the air quality status in all the states was good or satisfactory, except Uttar Pradesh, Jharkhand, and Odisha where air quality status was still moderate. The reason for this disparity has been discussed later.

Fig. 4 shows the time series for temporal variations in the NAQI observed in 115 Indian cities. The NAQI of Delhi, Mumbai, Kolkata, Chennai, and Hyderabad are highlighted separately to assess the impact of the nationwide lockdown on the air quality status in these cities. The temporal variations in the NAQI in 115 Indian cities including nationwide average and nationwide median show higher NAQI in January, February, until mid-March 2020. The NAQI nationwide average and nationwide median showed a decreasing trend during the observation period. The NAQI values in Indian cities were quite scattered, covering a range from satisfactory to very poor or even severe (Fig. 4). From mid-March to the end of April 2020, the nationwide average and nationwide median of NAQI decreased and maintained below 100 NAQI with satisfactory air quality status. This could be cumulative effects of improvement in air quality due to meteorological conditions and simultaneously reduction of emissions of air pollutants due to the nationwide lockdown. The NAQI in Delhi was higher from January to mid-March 2020 as compared to Mumbai and Kolkata. The NAQI in Delhi, Mumbai, and Kolkata were higher than the nationwide NAQI average, whereas, in Chennai and Hyderabad the NAQI was lower than the nationwide NAQI average (Fig. 4). 

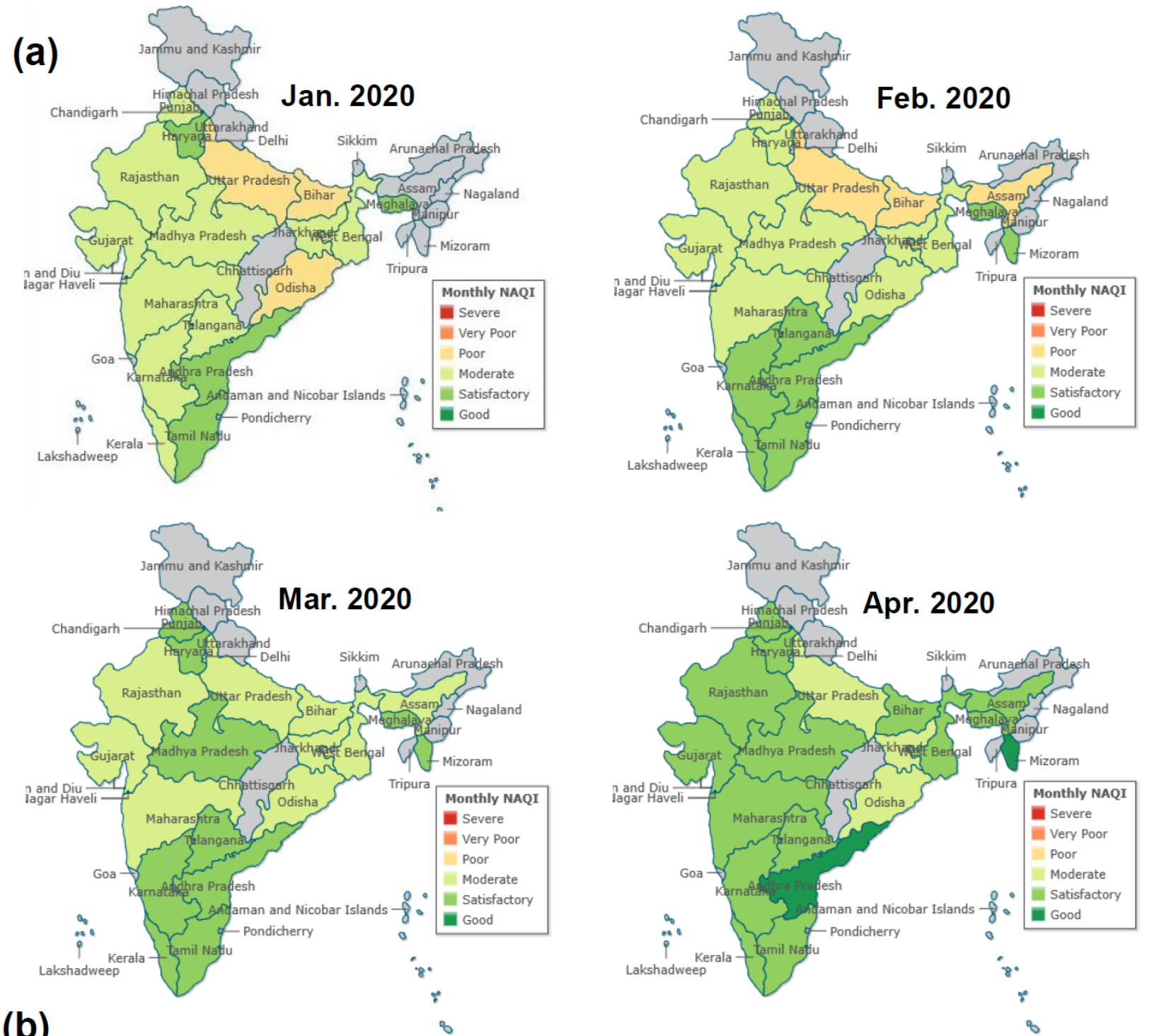

(b)

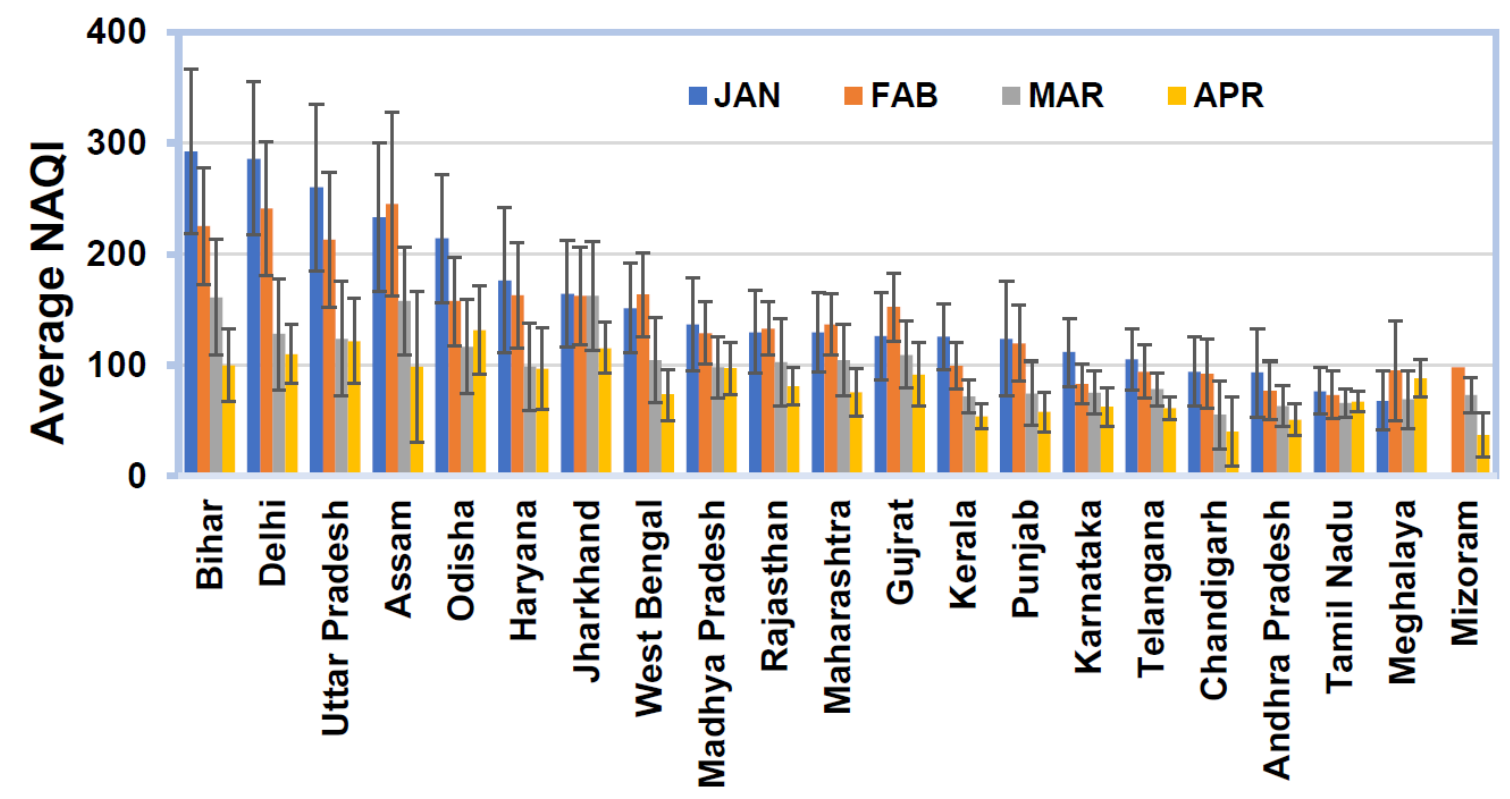

Fig. 3. National Air Quality Index (NAQI) in India from January to April 2020 (a) visual maps of the state-wise spatial distribution of monthly averaged NAQI and (b) monthly average \pm 1 standard deviation (SD) for each state. 


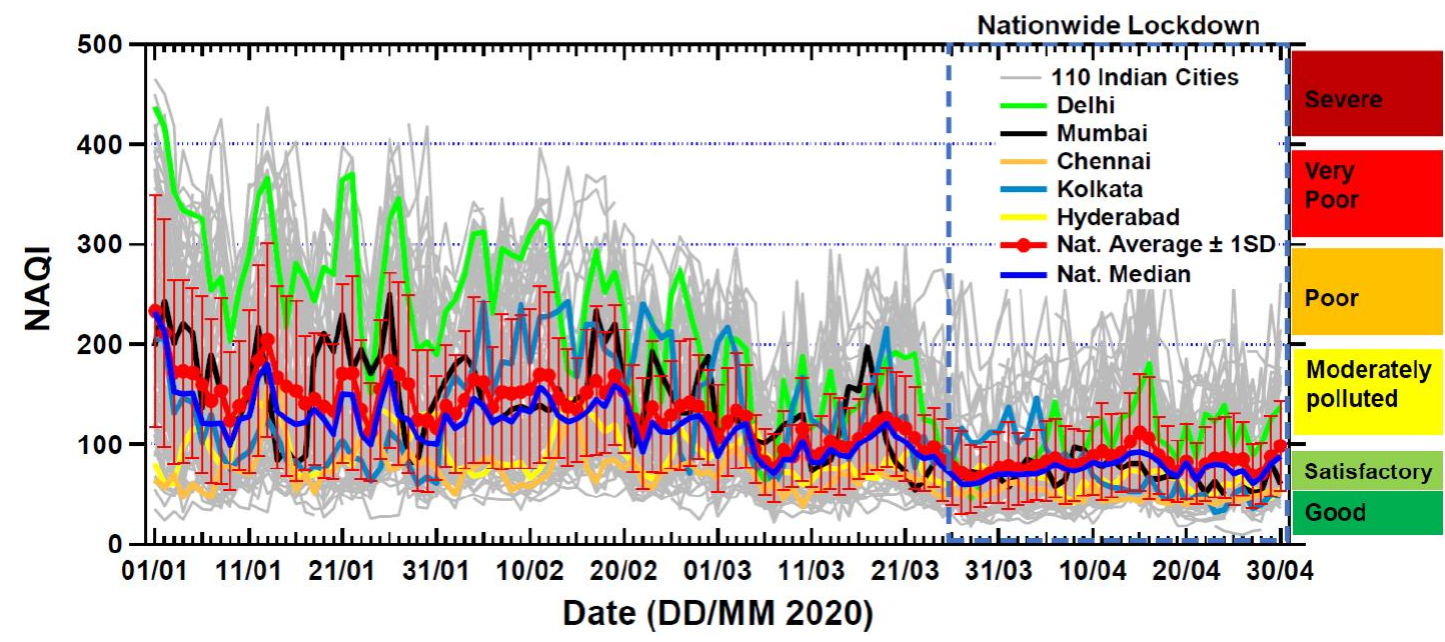

Fig. 4. Time-series of NAQI observed in 115 in Indian cities. Time-series of NAQI of Delhi, Mumbai, Kolkata, Chennai, and Hyderabad are highlighted separately. The nationwide average \pm 1 SD and nationwide median of NAQI is shown in Figure. The gridlines are labeled with color codes showing the categories of NAQI, as indicated in the NAQI guideline. The Figure is marked with a blue dash line to show the nationwide lockdown period.

\subsection{Satellite Visual Maps}

Fig. 5 shows the satellite visual maps of (a) $\mathrm{AOD}$, (b) $\mathrm{NO}_{2}$, (c) $\mathrm{CO}$, and (d) $\mathrm{SO}_{2}$. AOD is an excellent quantitative indicator for PM pollution and useful for estimation of $\mathrm{PM}_{2.5}$ surface concentration (Zhang et al., 2018; Krishna et al., 2019; Wang et al., 2019). The level of AOD over the IndoGangetic Plain (IGP) was large during January and February 2020, as similar patterns have been seen in the case of NAQI (Fig. 3(a)). The AOD was small in March 2020 and it was much smaller in April 2020 over central and north India, except in the eastern part of India.

Combustion is the main source of $\mathrm{NO}_{2}$, generally emitted from the transport, industrial, commercial, and residential sectors. In Fig. 5(b), the $\mathrm{NO}_{2}$ hotspots were seen in the urban regions of India. The $\mathrm{NO}_{2}$ hotspots were largely seen in north India including Delhi, Haryana, Punjab, Western Uttar Pradesh, and in the eastern part of India including Bihar, Jharkhand, West Bengal, and Odisha. Although the sources of $\mathrm{NO}_{2}$ emissions exist all over India, however, in the states of Delhi, Haryana, Punjab, Uttar Pradesh, Bihar, Jharkhand, West Bengal, and Odisha, they were predominantly more due to the dense population and industries. Also, these states are part of the IGP corridor where frequent stagnant meteorological conditions favor the accumulation of pollutants in the atmosphere (Dekker et al., 2019; Sawlani et al., 2019; Kanawade et al., 2020; Ojha et al., 2020).

In January 2020, there were many $\mathrm{NO}_{2}$ hotspots in the north and eastern part of India, which slightly decreased in February 2020. In March 2020, the $\mathrm{NO}_{2}$ hotspots almost disappeared from north India, while in April 2020 they disappeared from entire India, except few hot spots in the eastern part of India (Fig. 5(b)). The disappearance of $\mathrm{NO}_{2}$ hotspots in March and April 2020 could be attributed to the decreasing $\mathrm{NO}_{2}$ emissions from transport and industries, as both emission sources were suspended during the nationwide lockdown. The emissions of CO link with the combustion sources, hence the pattern of the $\mathrm{CO}$ in the satellite visual maps were the same as those of $\mathrm{NO}_{2}$ (Figs. 5(b) and 5(c)).

The hotspots of $\mathrm{SO}_{2}$ emissions were visible along the IGP corridor (Delhi, Uttar Pradesh, Bihar, Jharkhand) and in the eastern states of Odisha and West Bengal and south-western industrial regions in the states of Maharashtra and Gujrat (Fig. 5(d)). The main source of $\mathrm{SO}_{2}$ is coal-fired power plants and industries that use coal in the boilers. The intensity of $\mathrm{SO}_{2}$ emission hotspots in India was almost the same in January and February 2020. They decreased slightly in March 2020, however, still visible during April 2020 (Fig. 5(d)) despite the nationwide lockdown. As mentioned, power supply was classified as emergency service during the nationwide lockdown, so power generation was continued in the coal-fired power plants. Interestingly, high AOD and emission hotspots of $\mathrm{NO}_{2}, \mathrm{CO}$, and $\mathrm{SO}_{2}$ did not disappear in the states Odisha and Jharkhand in April 2020 (Fig. 5(a)-5(d)). Also, the NAQI was moderate in these states (Fig. 3(a) and 3(b)). This 
might be because in the states of Jharkhand and Odisha, large-scale coal mining is done, and these mines were likely operating during the nationwide lockdown to meet the demand for coal for power generation. Recently published regional emission inventory in Asia (REAS, version 3.1) by Kurokawa and Ohara (2020) has shown that the emissions of $\mathrm{NO}_{2}, \mathrm{CO}$, and $\mathrm{SO}_{2}$ were large in the eastern part of India where the states of Jharkhand and Odisha are located.

(a) AOD (at $550 \mathrm{~nm}$ )
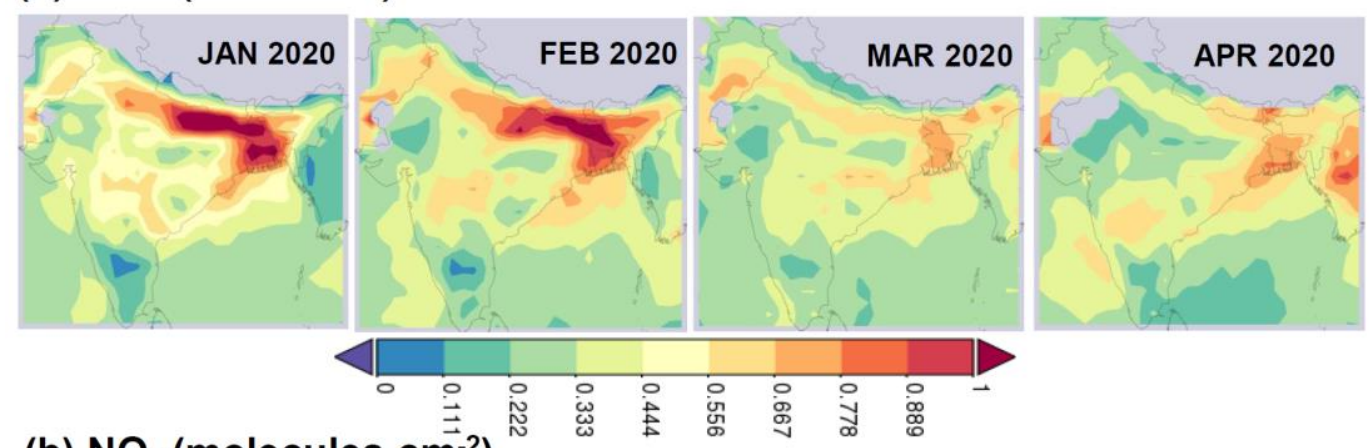

(b) $\mathrm{NO}_{2}$ (molecules $\mathrm{cm}^{-2}$ )
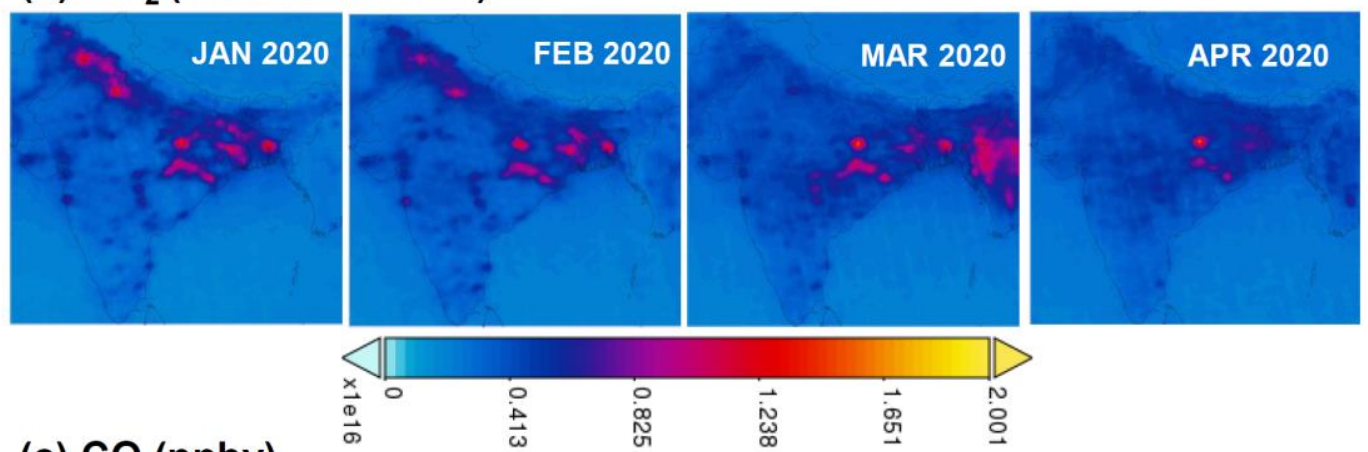

(c) $\mathrm{CO}$ (ppbv)
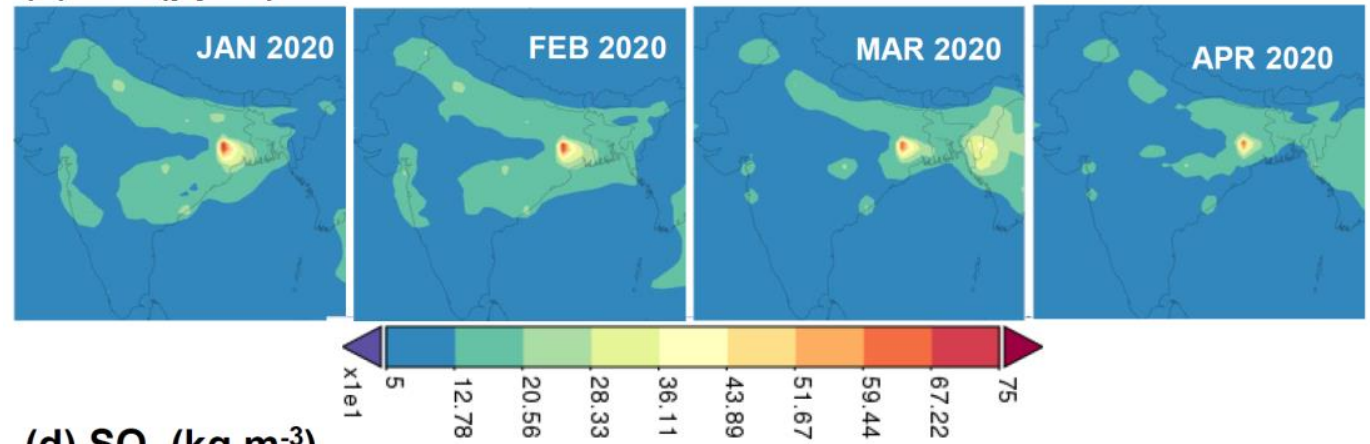

(d) $\mathrm{SO}_{2}\left(\mathrm{~kg} \mathrm{~m}^{-3}\right)$
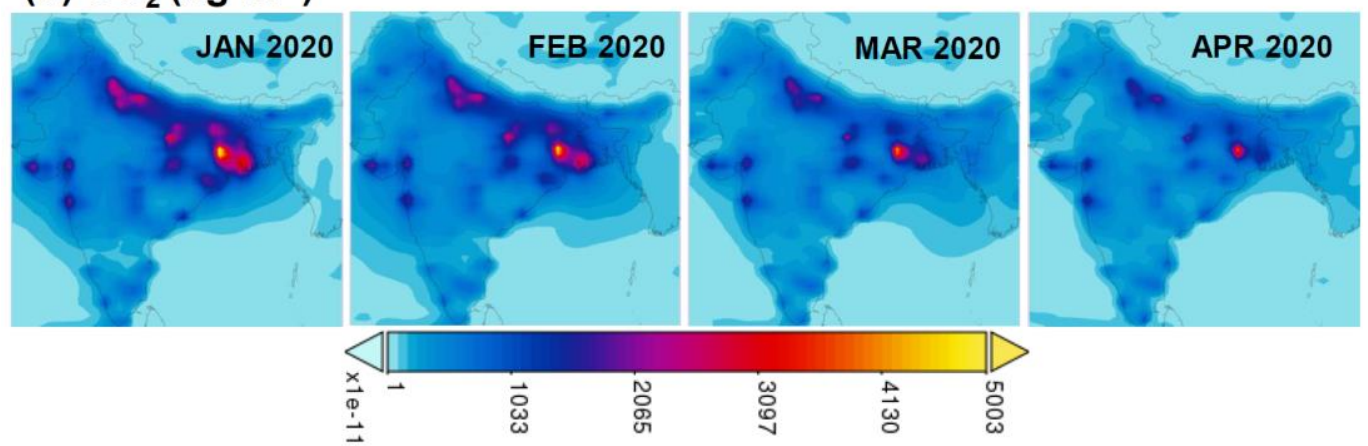

Fig. 5. Time-averaged visual maps of (a) Aerosol Optical Depth (AOD at $550 \mathrm{~nm}$ ), (b) $\mathrm{NO}_{2}$ total column (molecules $\mathrm{cm}^{-2}$ ) (c) $\mathrm{CO}$ surface concentration (ppbv), and (d) $\mathrm{SO}_{2}$ surface mass concentration $\left(\mathrm{kg} \mathrm{m}^{-3}\right)$ plotted online for each month on NASA's GIOVANNI website (https://giovanni.gsfc.nasa.gov/giovanni/) from January to April 2020. The geographical domain selected for India was $8 \mathrm{~N}^{\circ}-35.5 \mathrm{~N}^{\circ}$ and $68 \mathrm{E}^{\circ}-97 \mathrm{E}^{\circ}$. 


\subsection{Temporal Variations}

Figs. 6(a)-6(f) shows the time-series for temporal variations in the concentrations of $\mathrm{PM}_{10}$, $\mathrm{PM}_{2.5}, \mathrm{CO}, \mathrm{NO}_{2}, \mathrm{SO}_{2}$, and $\mathrm{O}_{3}$ from January to April 2020. Figs. 6(a)-6(f) included data available from CAAQMS (shown in Fig. 1), nationwide average \pm 1 SD, nationwide median, and 24-hour National Ambient Air Quality Standard (NAAQS) (except CO). There is no 24-hour NAAQS for CO.

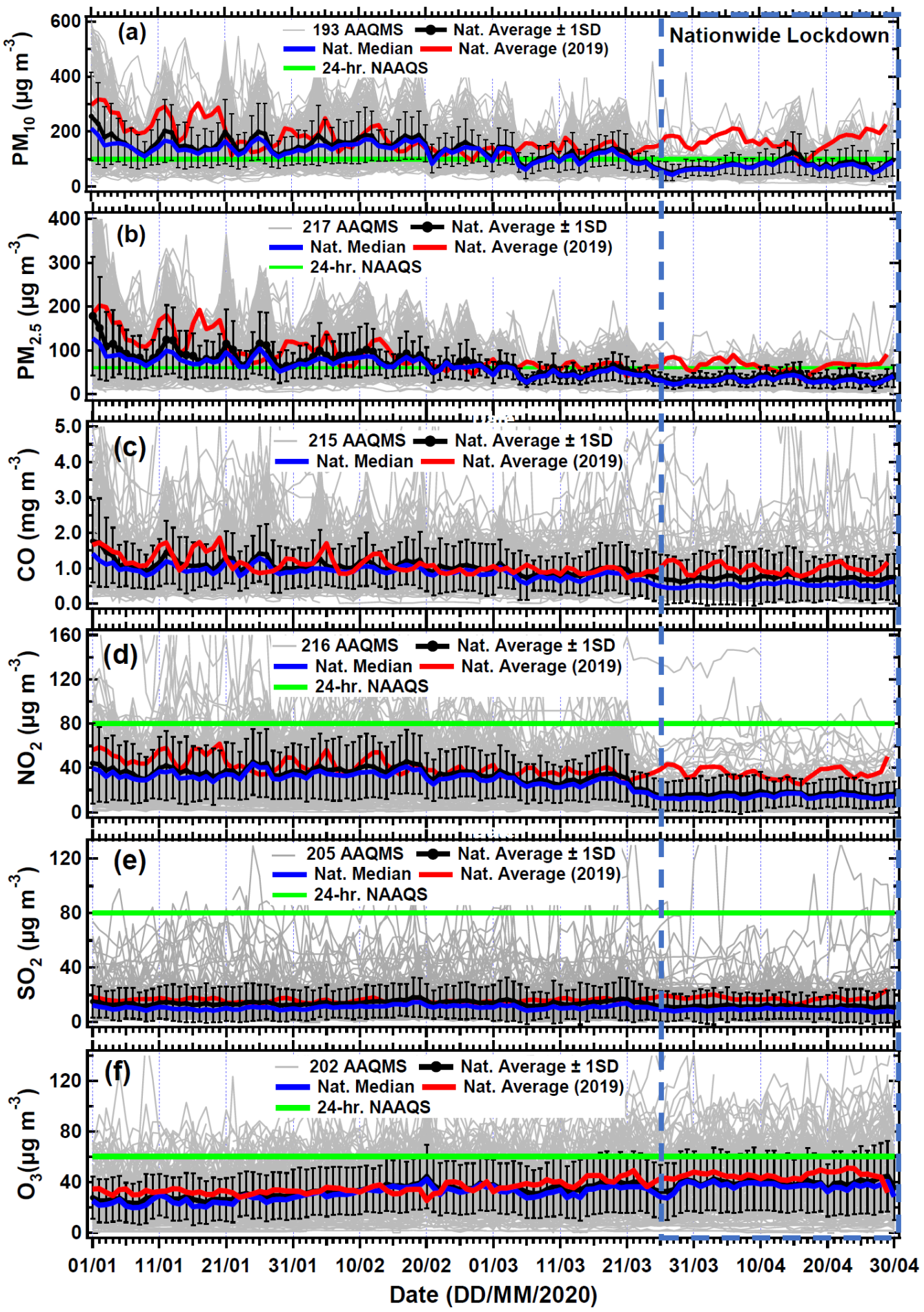

Fig. 6. Time-series of (a) $\mathrm{PM}_{10}$, (b) $\mathrm{PM}_{2.5}$, (c) $\mathrm{CO}$, (d) $\mathrm{NO}_{2}$, (e) $\mathrm{SO}_{2}$, and (f) $\mathrm{O}_{3}$ from January to April 2020. Figs. 6(a)-6(f) included data available from a number of CAAQMS for each parameter, nationwide average $\pm 1 \mathrm{SD}$, nationwide median, the nationwide average of 2019, and 24-hour national ambient air quality standard (except CO). The nationwide lockdown period ( $25 \mathrm{March}-$ 30 April 2020) is also indicated as a blue dashed line. 
The nationwide lockdown period (25 March-30 April 2020) was also indicated as a blue dashed line in Fig. 6. In Figs. 6(a)-6(f) the nationwide average concentrations of $\mathrm{PM}_{10}, \mathrm{PM}_{2.5}, \mathrm{CO}, \mathrm{NO}_{2}$, $\mathrm{SO}_{2}$, and $\mathrm{O}_{3}$ observed from January to April 2019 at the same CAAQMS were also included for showing a better comparison of the concentration levels of air pollutants, especially during the nationwide lockdown period.

The temporal variations in the concentrations of $\mathrm{PM}_{10}, \mathrm{PM}_{2.5}, \mathrm{CO}$, and $\mathrm{NO}_{2}$ show a similar trend which shows proximity in the emission sources of these pollutants, such as fossil fuels combustion in transport, industries, residential and commercial activities (Figs. 6(a)-6(d)). The $\mathrm{PM}_{10}$ and $\mathrm{PM}_{2.5}$ concentrations were quite high at a few CAAQMS during January and February 2020 (Figs. 6(a) and $6(b))$, however, their concentrations systematically decreased with time. The nationwide average and nationwide median concentrations of $\mathrm{PM}_{10}$ and $\mathrm{PM}_{2.5}$ continuously shown a decreasing trend from January to mid-March 2020. The nationwide average concentrations of $P M_{10}$ and $P M_{2.5}$ observed from January to April 2019 have also shown a similar decreasing trend, but their levels were higher in January and February 2019 compared to those in January and February 2020. From February to mid-March, the nationwide average concentration of $\mathrm{PM}_{10}$ and $\mathrm{PM}_{2.5}$ both in 2019 and 2020 were almost the same. Afterward, the nationwide average concentrations of $P_{10}$ and $\mathrm{PM}_{2.5}$ of 2019 have remained almost steady, whereas the nationwide average concentrations of $\mathrm{PM}_{10}$ and $\mathrm{PM}_{2.5}$ of 2020 decreased significantly, which could be attributed to the impacts of the nationwide lockdown (Figs. 6(a) and 6(b)).

The nationwide average and nationwide median concentrations of $\mathrm{PM}_{10}$ and $\mathrm{PM}_{2.5}$ in 2020 and the nationwide average concentrations $\mathrm{PM}_{10}$ and $\mathrm{PM}_{2.5}$ in 2019 were higher than the 24-hour NAAQS for $\mathrm{PM}_{10}$ and $\mathrm{PM}_{2.5}$ from January to mid of March. Afterward, from March 21, 2020, both the nationwide average and nationwide median concentrations of $\mathrm{PM}_{10}$ and $\mathrm{PM}_{2.5}$ were lower than the 24-hour NAAQS (Figs. 6(a) and 6(b)). The lower nationwide average and nationwide median concentrations of $\mathrm{PM}_{10}$ and $\mathrm{PM}_{2.5}$ during the nationwide lockdown as compared to their 24-hour NAAQS provided a new nationwide baseline data for the $\mathrm{PM}_{10}$ and $\mathrm{PM}_{2.5}$.

Like $\mathrm{PM}_{10}$ and $\mathrm{PM}_{2.5}$, the nationwide average and nationwide median concentrations of $\mathrm{CO}$ and $\mathrm{NO}_{2}$ were higher during January 2020 which subsequently decreased with time. The nationwide average of $\mathrm{CO}$ and $\mathrm{NO}_{2}$ in January 2019 was higher as compared to those observed in January 2020. However, during February and March in both 2019 and 2020, the nationwide average and nationwide median concentrations of $\mathrm{CO}$ and $\mathrm{NO}_{2}$ were almost similar (Figs. 6(c) and 6(d)), which implied that the magnitude of $\mathrm{CO}$ and $\mathrm{NO}_{2}$ emissions were not changed significantly during both years. After mid-March, the nationwide average concentrations of $\mathrm{CO}$ and $\mathrm{NO}_{2}$ has remained steady in 2019, while the nationwide average and nationwide median concentrations of $\mathrm{CO}$ and $\mathrm{NO}_{2}$ in 2020 has been decreased significantly during the nationwide lockdown (Figs. 6(c) and $6(\mathrm{~d})$ ). The 24-hour NAAQS of $\mathrm{NO}_{2}$ was always higher than the nationwide average and nationwide median concentrations (Fig. 6(d)).

The temporal variations in the concentrations of $\mathrm{SO}_{2}$ were quite different than those of $\mathrm{PM}_{10}$, $\mathrm{PM}_{2.5}, \mathrm{CO}$, and $\mathrm{NO}_{2}$ (Figs. 6(a)-6(e)The nationwide average and nationwide median concentrations of $\mathrm{SO}_{2}$ observed from January to March 2020 had remained steady. During the nationwide lockdown, a slight decrease in the concentrations of nationwide average and nationwide median of $\mathrm{SO}_{2}$ was observed compared to those observed in April 2019. The 24-hour NAAQS of $\mathrm{SO}_{2}$ was always higher than the nationwide average and nationwide median of $\mathrm{SO}_{2}$ (Fig. 6(d)).

$\mathrm{O}_{3}$ is a secondary pollutant. Ground-level $\mathrm{O}_{3}$ is formed during photochemical chain reactions between oxides of nitrogen $\left(\mathrm{NO}_{\mathrm{x}}\right)$, volatile organic compounds (VOCs), and CO. The temporal variations in the nationwide average and the nationwide median concentrations of $\mathrm{O}_{3}$ showed a consistently increasing trend from January to April 2020 including during the nationwide lockdown (Fig. 6(f)). Almost the same trend has been shown by the nationwide average concentrations of $\mathrm{O}_{3}$ observed from January to April 2019. However, the nationwide average and nationwide median concentrations of $\mathrm{O}_{3}$ observed during the nationwide lockdown were slightly lower than those in April 2019. The increasing trend in the temporal variations in the $\mathrm{O}_{3}$ concentrations was quite opposite to that shown by primary key pollutants including during the nationwide lockdown (Figs. 6(a)-6(d)). It was expected that during the nationwide lockdown, since the precursors of $\mathrm{O}_{3}$, (e.g., $\mathrm{NO}_{2}$ and $\mathrm{CO}$ ) have shown a decreasing trend (Figs. 6(c) and 6(d)), the $\mathrm{O}_{3}$ concentrations were also expected to show a decreasing trend.

To investigate the increasing trend in the concentration of $\mathrm{O}_{3}$, time-averaged satellite visual 
maps of $\mathrm{O}_{3}$ and Incoming Shortwave Flux were plotted from January-April 2020 for each month, shown in Figs. 7(a) and 7(b), respectively. As can be seen in Figs. 7(a) and 7(b), the spatial distribution of concentrations of $\mathrm{O}_{3}$ were kept increasing from January-April 2020, in particular over north India, along with incoming shortwave flux. This implied that despite the decreasing trend in the concentrations of $\mathrm{O}_{3}$ precursors (e.g., $\mathrm{NO}_{2}$ and $\mathrm{CO}$ ) at ground level observations (Figs. 6(c) and 4(d)), there were enough emissions of $\mathrm{NO}_{2}, \mathrm{CO}$, and probably VOCs which causes the formation of $\mathrm{O}_{3}$ in northern India. The emissions of $\mathrm{NO}_{2}, \mathrm{CO}$, and VOCs might be from the burning of biofuels in domestic cooking in remote or rural regions of India since the burning of biofuels are a big source of $\mathrm{O}_{3}$ precursors in north India (Pallavi et al., 2019; Jat et al., 2020). It may be noted that the observation sites, shown in Fig. 1, are mostly located in urban regions of India which failed to capture the emissions of $\mathrm{O}_{3}$ precursors from rural or remote areas. The 24hour NAAQS of $\mathrm{O}_{3}$ was always higher than the nationwide average concentration of $\mathrm{O}_{3}$ during both 2019 and 2020 (Fig. 6(f)).

\subsection{Statistical Analysis}

Tables 1(a)-1(f) shows statistical analysis of change in the average concentrations ( $\pm 1 \mathrm{SD}$ ) of $\mathrm{PM}_{10}, \mathrm{PM}_{2.5}, \mathrm{CO}, \mathrm{NO}_{2}, \mathrm{SO}_{2}$, and $\mathrm{O}_{3}$ nationwide and in Delhi, Mumbai, Kolkata, Chennai, and Hyderabad during January and April 2020 including before the lockdown and during the lockdown and those observed in April 2019. Figs. 8(a1)-8(f1) and 8(a2)-8(f2) graphically represents the change in the average ( $\pm 1 \mathrm{SD}$ ) concentrations of $\mathrm{PM}_{10}, \mathrm{PM}_{2.5}, \mathrm{CO}, \mathrm{NO}_{2}, \mathrm{SO}_{2}$, and $\mathrm{O}_{3}$ during the lockdown with the period before the lockdown (left panels: a1-f1) and the change in average ( $\pm 1 \mathrm{SD}$ ) concentrations of $\mathrm{PM}_{10}, \mathrm{PM}_{2.5}, \mathrm{CO}, \mathrm{NO}_{2}, \mathrm{SO}_{2}$, and $\mathrm{O}_{3}$ with average concentrations of these parameters observed in April 2019 (right panels: a2-f2) at nationwide and in Delhi, Mumbai, Kolkata, Chennai, and Hyderabad. Among these cities, Mumbai, Kolkata, and Chennai are the

\section{(a) $\mathrm{O}_{3}$ (ppbv)}

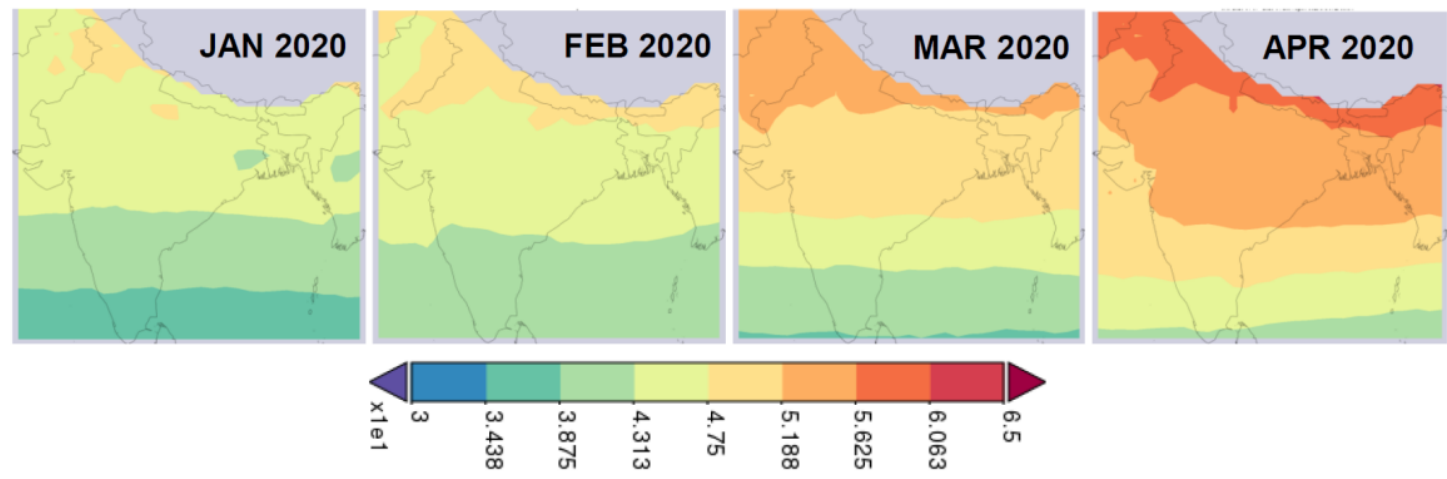

\section{(b) Incoming Shortwave Flux (W m-2)}

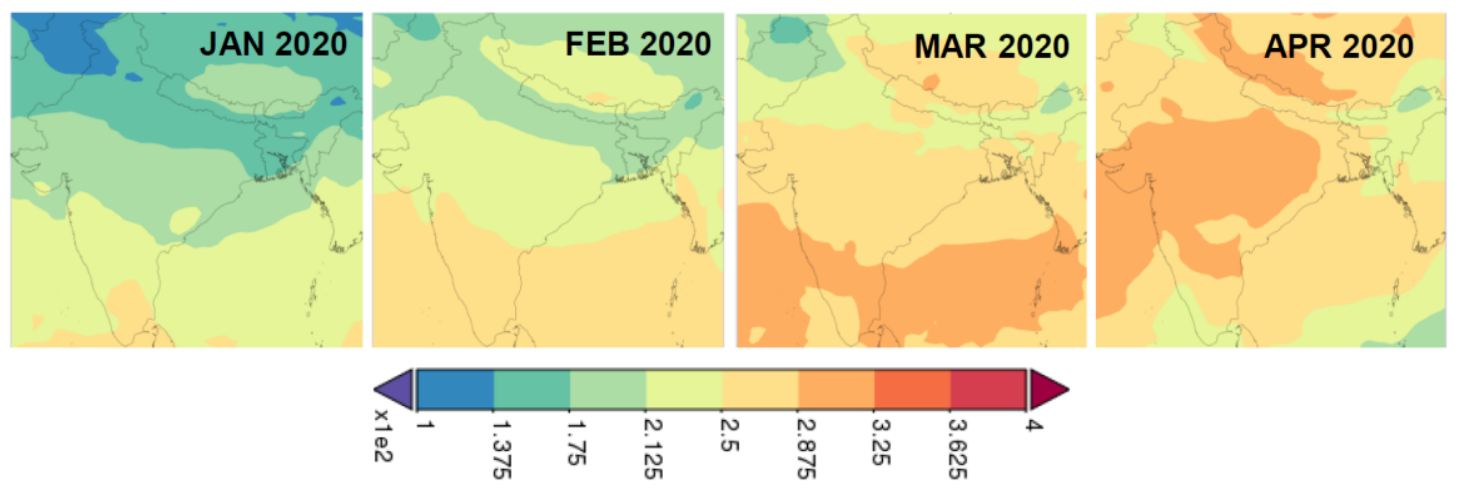

Fig. 7. Time-averaged satellite visual maps of (a) Ozone $\left(\mathrm{O}_{3}\right)$ (mole fraction air (ppbv), nighttime/descending, AIRS3STD v006, 1 deg., @700 hPa) and (b) Incoming Shortwave Flux (W m ${ }^{-2}$, MERRA-2 Model M2T1NXRAD v5.12.4, $0.5 \times 0.625$ deg.) for each month from January to April 2020, plotted online on NASA's GIOVANNI website (https://giovanni.gsfc.nasa.gov/giovanni/). 


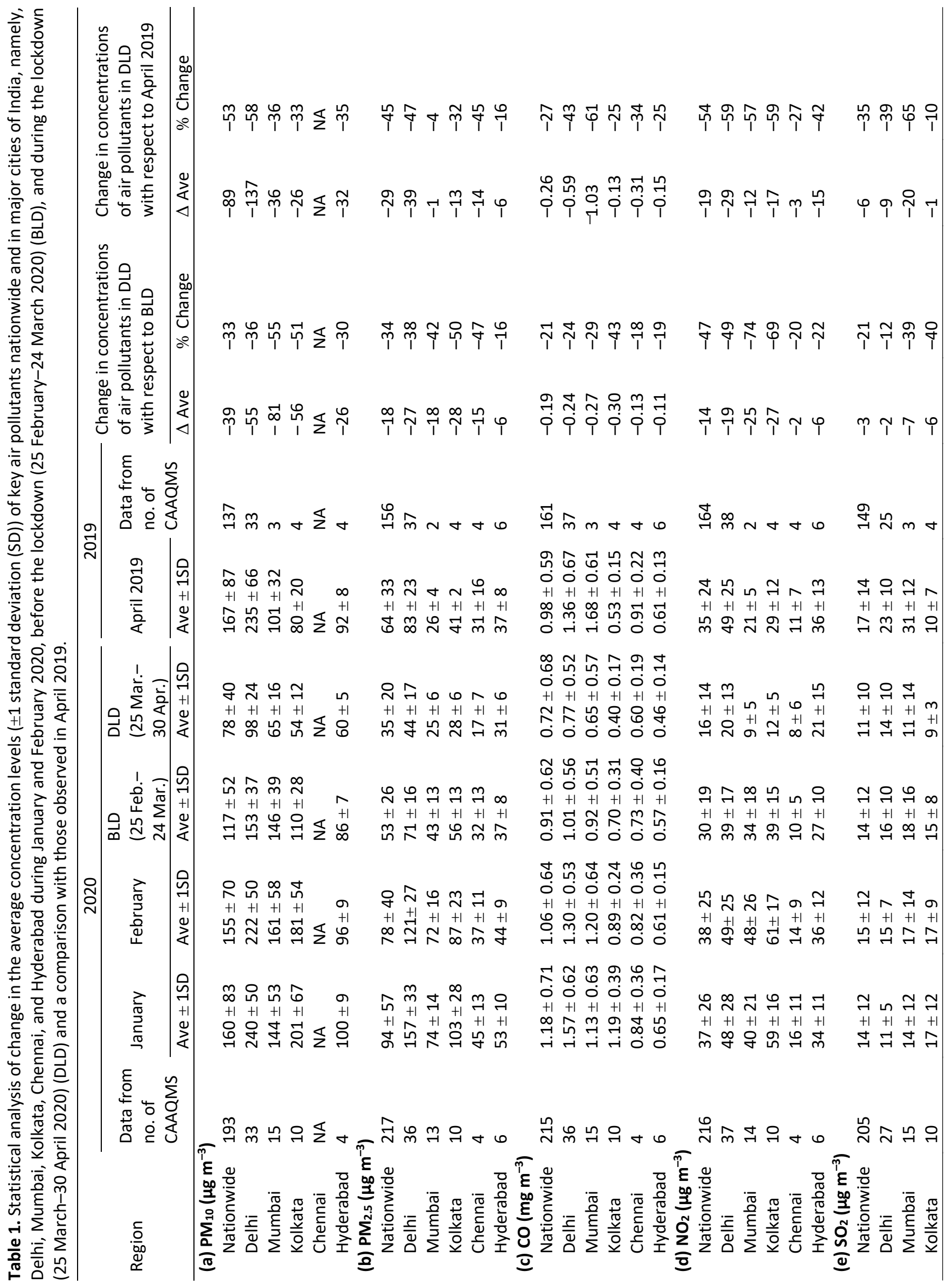




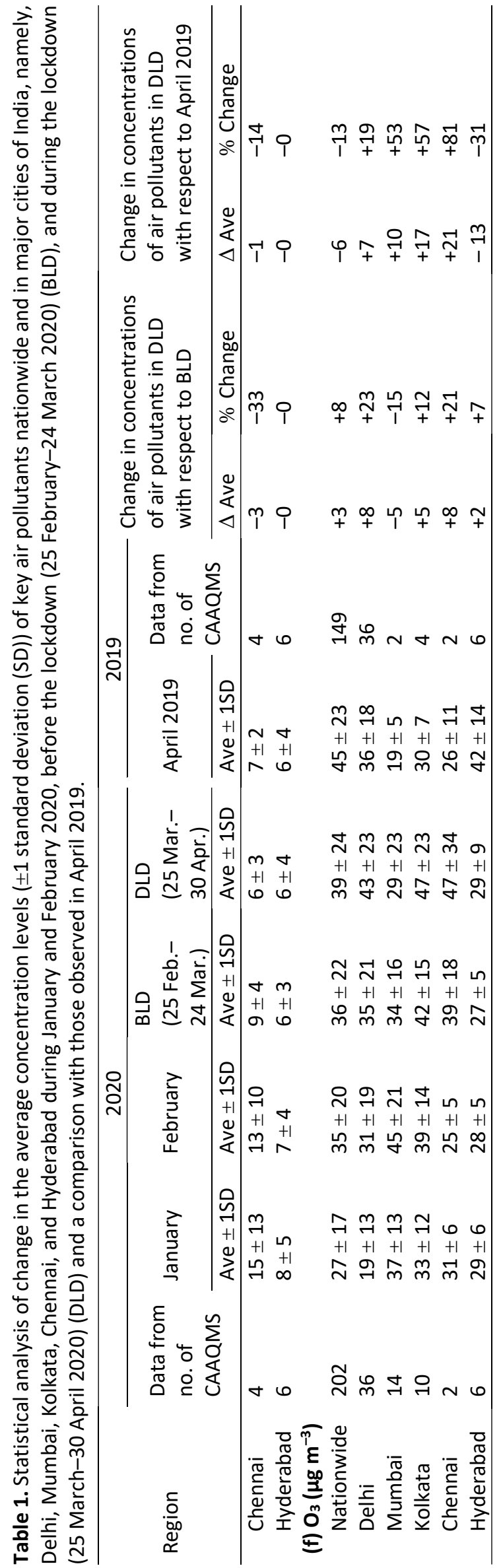


coastal cities while Delhi and Hyderabad have located hinterland quite far from the coastal environment. These cities are located in different parts of the country. For example, Delhi is situated in the north, Mumbai in the west, Kolkata in the east, Chennai in the south, and Hyderabad in the south but far from the coastal environment. These five cities represented the major urban conglomerates of India.

The nationwide average concentrations of $\mathrm{PM}_{10}$ were 160 and $155 \mu \mathrm{g} \mathrm{m}^{-3}$ in January and February of 2020, respectively. The nationwide $\mathrm{PM}_{10}$ average concentrations before the lockdown and during the lockdown were 117 and $78 \mu \mathrm{g} \mathrm{m}{ }^{-3}$, respectively. On comparing, the nationwide $\mathrm{PM}_{10}$ average concentration observed during the lockdown with that before the lockdown, it was found that PM10 nationwide average concentration decreased by 33\% (Fig. 8(a1) and Table 1(a)). The nationwide $\mathrm{PM}_{10}$ average concentration observed in April 2019 at the same CAAQMS was $167 \mu \mathrm{g} \mathrm{m}^{-3}$. The nationwide $\mathrm{PM}_{10}$ average concentration observed during the lockdown decreased by $53 \%$ when compared with $\mathrm{PM}_{10}$ nationwide average concentrations of April 2019 (Fig. 8(a2) and Table 1(a)). In Delhi, Mumbai, Kolkata, and Hyderabad, the average $\mathrm{PM}_{10}$ concentrations observed in January 2020 were 240, 144, 201, and $100 \mu \mathrm{g} \mathrm{m}^{-3}$, respectively. The $\mathrm{PM}_{10}$ average concentrations in these four cities in February 2020 were 222, 161, 181, and $96 \mu \mathrm{g} \mathrm{m}^{-3}$, respectively. Before the lockdown, the average $\mathrm{PM}_{10}$ concentrations in Delhi, Mumbai, Kolkata, and Hyderabad were 153, 146, 110, and $86 \mathrm{\mu g} \mathrm{m}^{-3}$, respectively, while during the lockdown, $\mathrm{PM}_{10}$ concentrations have decreased to $98,65,54$, and $60 \mu \mathrm{g} \mathrm{m}^{-3}$ in Delhi, Mumbai, Kolkata, and Hyderabad, respectively. It was found that average $\mathrm{PM}_{10}$ concentrations decreased by $36,55,51$, and $30 \%$ in Delhi, Mumbai, Kolkata, and Hyderabad, respectively, during the lockdown as compared to those before the lockdown in these cities (Fig. 8(a1) and Table 1(a)). In Mumbai and Kolkata, the percentage decrease in $\mathrm{PM}_{10}$ average concentrations during the lockdown was nearly $50 \%$, higher than Delhi and Hyderabad. This could be an additional impact of the coastal environment where the land-sea breeze circulation brought clean air from the ocean to the land which helps in diluting the polluted air. During April 2019, the average $\mathrm{PM}_{10}$ concentrations in Delhi, Mumbai, Kolkata, and Hyderabad were 235, 101, 80, and $92 \mu \mathrm{g} \mathrm{m}^{-3}$, when compared these average $\mathrm{PM}_{10}$ concentrations with those observed during the lockdown in these cities, it was found that $\mathrm{PM}_{10}$ concentrations decreased by 58, 36, 33, and 35\% in Delhi, Mumbai, Kolkata, and Hyderabad, respectively (Fig. 8(a2) and Table 1(a)).

The nationwide average concentrations of $\mathrm{PM}_{2.5}$ in January and February 2020 were 94 and 78 $\mu \mathrm{g} \mathrm{m}^{-3}$, respectively. While, the nationwide $\mathrm{PM}_{2.5}$ average concentrations before the lockdown and during the lockdown were 53 and $35 \mu \mathrm{g} \mathrm{m}^{-3}$, respectively. Comparing the nationwide $\mathrm{PM}_{2.5}$ average concentration of the lockdown with that before the lockdown, the $\mathrm{PM}_{2.5}$ concentration decreased by $34 \%$ during the lockdown with that before the lockdown (Fig. 8(b1) and Table 1(b)). The nationwide $\mathrm{PM}_{2.5}$ average concentration observed in April 2019 was $64 \mu \mathrm{g} \mathrm{m}^{-3}$. On comparing the nationwide $\mathrm{PM}_{2.5}$ average concentrations of the lockdown with that observed in April 2019, it was found to have decreased by $45 \%$ (Fig. 8(b2) and Table 1(b)). In Delhi, Mumbai, Kolkata, Chennai, and Hyderabad, the average PM2.5 concentrations were 157, 74, 103, 45, and $53 \mu \mathrm{g} \mathrm{m}^{-3}$, respectively, in January 2020. Whereas, in February 2020, the average of $\mathrm{PM}_{2.5}$ concentrations in Delhi, Mumbai, Kolkata, Chennai, and Hyderabad were $121,72,87,37$, and $44 \mu \mathrm{g} \mathrm{m}^{-3}$, respectively. Before the lockdown, the average of $\mathrm{PM}_{2.5}$ concentrations in Delhi, Mumbai, Kolkata, Chennai, and Hyderabad was $71,43,56,32$, and $37 \mu \mathrm{g} \mathrm{m}^{-3}$, respectively, which reduced to $44,25,28,17$, and $31 \mu \mathrm{g} \mathrm{m}^{-3}$, respectively, in these cities during the lockdown, and showing a reduction of 38 , 42, 50, 47, and 16\%, respectively (Fig. 8(b1) and Table 1(b)). Like $\mathrm{PM}_{10}$, the percentage decrease in $\mathrm{PM}_{2.5}$ average concentrations in the coastal cities of Mumbai, Kolkata, and Chennai during the lockdown was higher than in land-locked cities of Delhi and Hyderabad, which could be cumulative effects of the lockdown and coastal environment that promote dilution of air through land-sea breeze circulation. During April 2019, the average $\mathrm{PM}_{2.5}$ concentrations in Delhi, Mumbai, Kolkata, Chennai, and Hyderabad were 83, 26, 41, 31, and $37 \mu \mathrm{g} \mathrm{m}^{-3}$, respectively. When compared, the average $\mathrm{PM}_{2.5}$ concentrations of April 2019 with the average $\mathrm{PM}_{2.5}$ concentrations observed during the lockdown in Delhi, Mumbai, Kolkata, Chennai, and Hyderabad, it was found that average $\mathrm{PM}_{2.5}$ concentrations were decreased by $47,4,32,45$, and $16 \%$, respectively, during the lockdown (Fig. 8(b2) and Table 1(b)).

The nationwide $\mathrm{CO}$ average concentrations during January and February 2020 were 1.18 and $1.06 \mathrm{mg} \mathrm{m}^{-3}$, respectively. Whereas, the nationwide $\mathrm{CO}$ average concentration before the 
(a1)
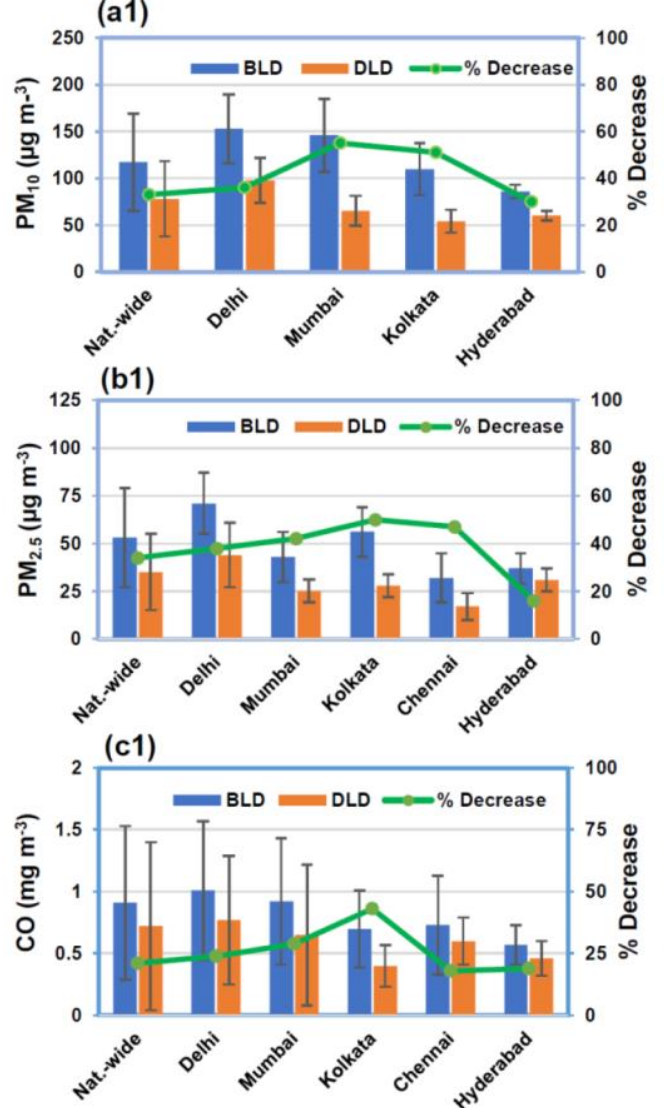

(d1)
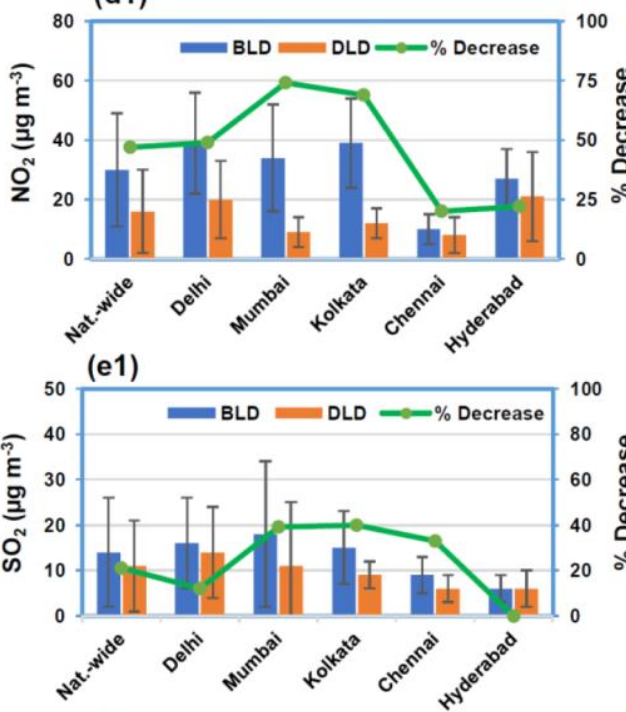

(f1)

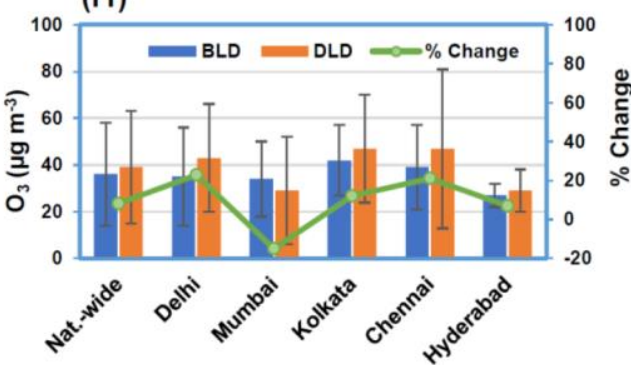

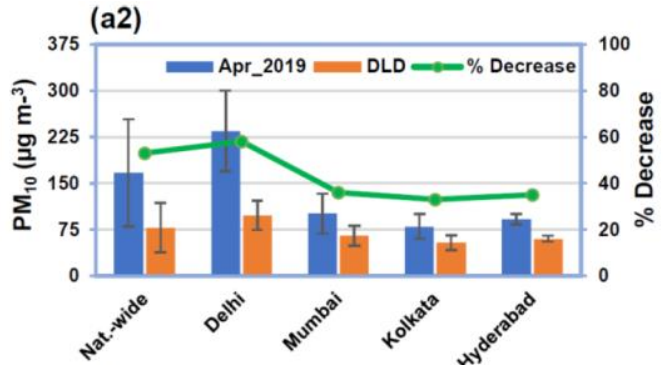

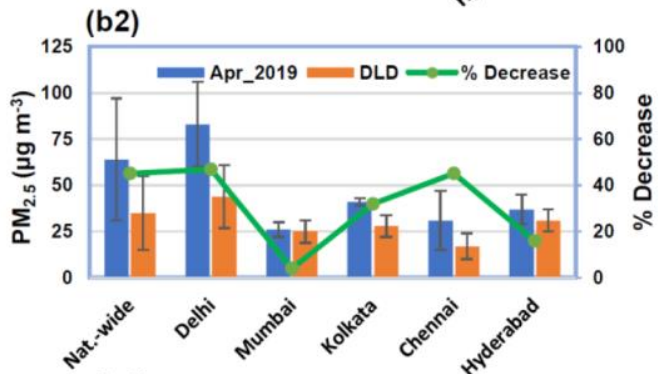

(c2)

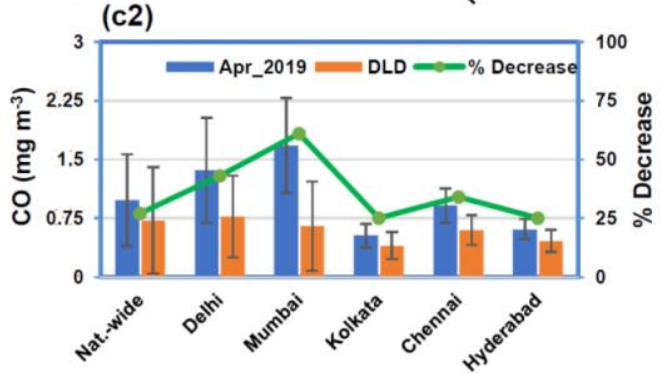

(d2)
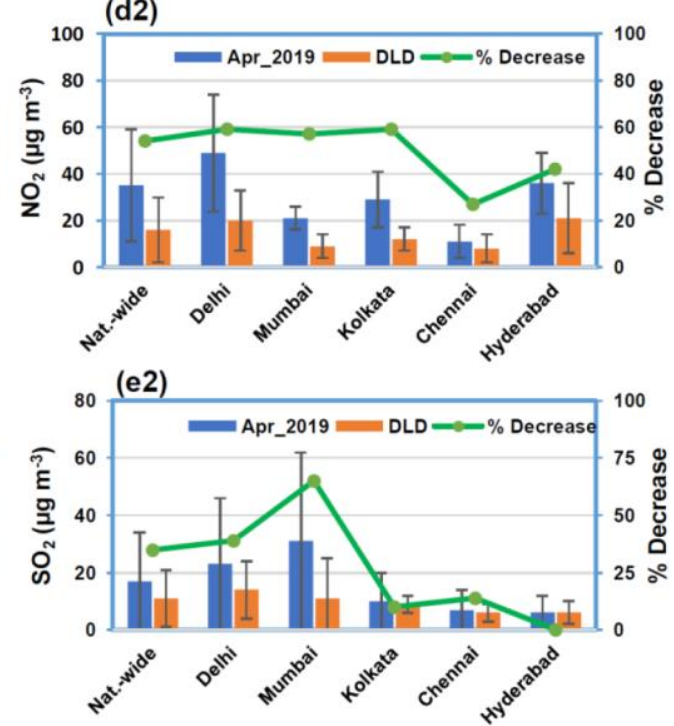

(f2)

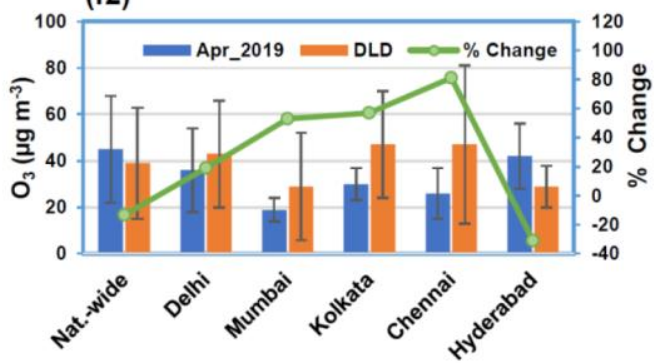

Fig. 8. Change in average concentration ( $\pm 1 \mathrm{SD}$ ) levels of $\mathrm{PM}_{10}, \mathrm{PM}_{2.5}, \mathrm{CO}, \mathrm{NO}_{2}, \mathrm{SO}_{2}$, and $\mathrm{O}_{3}$ during the lockdown (DLD) with respect to before the lockdown (BLD) (left panels: a1-f1) and with respect to average concentration ( \pm 1 SD) levels of those observed in April 2019 (right panels: a2-f2) nationwide and in Delhi, Mumbai, Kolkata, Chennai, and Hyderabad. 
lockdown and during the lockdown were 0.91 and $0.72 \mathrm{mg} \mathrm{m}^{-3}$, respectively. The nationwide average $\mathrm{CO}$ concentration decreased by $21 \%$ during the lockdown compared to that before the lockdown (Fig. 8(c1) and Table 1(c)). The nationwide average CO concentration during April 2019 was 0.98 in $\mathrm{mg} \mathrm{m}^{-3}$. The nationwide average CO concentration decreased by $27 \%$ during the lockdown with that observed in April 2019 (Fig. 8(c2) and Table 1(c)). In Delhi, Mumbai, Kolkata, Chennai, and Hyderabad, the average CO concentrations were 1.57, 1.13, 1.19, 0.84, and $0.65 \mathrm{mg} \mathrm{m}^{-3}$, respectively, in January 2020 and $1.30,1.20,0.89,0.82$, and $0.61 \mathrm{mg} \mathrm{m}^{-3}$, respectively, in February 2020. Before the lockdown, the average CO concentrations were $1.01,0.92,0.70$, 0.73, and $0.57 \mathrm{mg} \mathrm{m}^{-3}$ in Delhi, Mumbai, Kolkata, Chennai, and Hyderabad, respectively. While during the lockdown, the average CO concentrations were $0.77,0.65,0.40,0.60$, and $0.46 \mathrm{mg} \mathrm{m}^{-3}$ in Delhi, Mumbai, Kolkata, Chennai, and Hyderabad, respectively. It was found that during the lockdown, the average CO concentrations decreased by $24,29,43,18$, and $19 \%$ in Delhi, Mumbai, Kolkata, Chennai, and Hyderabad, respectively, with those observed before the lockdown (Fig. 8(c1) and Table 1(c)). The average CO concentrations observed in April 2019 in Delhi, Mumbai, Kolkata, Chennai, and Hyderabad were 1.36, 1.68, $0.53,0.91$, and $0.61 \mathrm{mg} \mathrm{m}^{-3}$, respectively. When compared the average $\mathrm{CO}$ concentrations of these cities during the lockdown period with those during April 2019, the average CO concentrations have decreased by 43, 61, 25, 34, and $25 \%$ during the lockdown in Delhi, Mumbai, Kolkata, Chennai, and Hyderabad, respectively (Fig. 8(c2) and Table 1(c)).

The nationwide average $\mathrm{NO}_{2}$ concentrations during January and February 2020 were 37 and $38 \mathrm{~g} \mathrm{~m}^{-3}$, respectively. Whereas, before the lockdown and during the lockdown, the nationwide average $\mathrm{NO}_{2}$ concentrations were 30 and $16 \mu \mathrm{g} \mathrm{m}^{-3}$, respectively. The nationwide average $\mathrm{NO}_{2}$ concentration was decreased by $47 \%$ during the lockdown with respect to what it was before the lockdown (Fig. 8(d1) and Table 1(d)). The nationwide average $\mathrm{NO}_{2}$ concentration in April 2019 was $35 \mu \mathrm{g} \mathrm{m}^{-3}$. The nationwide average $\mathrm{NO}_{2}$ concentration has reduced by $54 \%$ during the lockdown when compared with that of April 2019 (Fig. (8d2) and Table 1(d)). In Delhi, Mumbai, Kolkata, Chennai, and Hyderabad, the average $\mathrm{NO}_{2}$ concentrations were 48, 40,59, 16, and $34 \mathrm{~g} \mathrm{~m}^{-3}$, respectively, in January 2020 and 49, 48, 61, 14, and $36 \mu \mathrm{g} \mathrm{m}^{-3}$, respectively, in February 2020. Before the lockdown, the average $\mathrm{NO}_{2}$ concentrations were 39, 34, 39, 10, and $27 \mu \mathrm{g} \mathrm{m}^{-3}$ in Delhi, Mumbai, Kolkata, Chennai, and Hyderabad, respectively. While during the lockdown, the average $\mathrm{NO}_{2}$ concentrations were $20,9,12,8$, and $21 \mu \mathrm{g} \mathrm{m}^{-3}$ in Delhi, Mumbai, Kolkata, Chennai, and Hyderabad, respectively. It was observed that during the lockdown, the average $\mathrm{NO}_{2}$ concentrations decreased by $49,74,69,20$, and $22 \%$ in Delhi, Mumbai, Kolkata, Chennai, and Hyderabad, respectively, when compared with average $\mathrm{NO}_{2}$ concentrations before the lockdown in these cities (Fig. 8(d1) and Table $1(\mathrm{~d})$ ). The observation suggests that the average $\mathrm{NO}_{2}$ concentration decrease was the highest in Mumbai and lowest in Chennai. The average $\mathrm{NO}_{2}$ concentrations observed in April 2019 in Delhi, Mumbai, Kolkata, Chennai, and Hyderabad were $49,21,29,11$, and $36 \mu \mathrm{g} \mathrm{m}^{-3}$, respectively. When compared with the average $\mathrm{NO}_{2}$ concentrations of the lockdown period with those observed in April 2019, it appeared that average $\mathrm{NO}_{2}$ concentrations decreased by $59,57,59,27$, and $42 \%$ in Delhi, Mumbai, Kolkata, Chennai, and Hyderabad, respectively (Fig. 8(d1) and Table 1(d)).

The nationwide average $\mathrm{SO}_{2}$ concentrations during January and February 2020 were 14 and $15 \mu \mathrm{g} \mathrm{m}^{-3}$, respectively, and the nationwide average $\mathrm{SO}_{2}$ concentrations before the lockdown and during the lockdown were 14 and $11 \mu \mathrm{g} \mathrm{m} \mathrm{m}^{-3}$, respectively. The nationwide average $\mathrm{SO}_{2}$ concentration was decreased by $21 \%$ with that observed before the lockdown (Fig. 8(e1) and Table 1(e)). The nationwide average $\mathrm{SO}_{2}$ concentration during April 2019 was $17 \mu \mathrm{g} \mathrm{m}^{-3}$. The nationwide $\mathrm{SO}_{2}$ average concentration was decreased by $35 \%$ during the lockdown period with that observed in April 2019 (Fig. 8(e1) and Table 1(e)). In Delhi, Mumbai, Kolkata, Chennai, and Hyderabad, the average $\mathrm{SO}_{2}$ concentrations were $11,14,17,15$, and $8 \mu \mathrm{g} \mathrm{m}^{-3}$, respectively, in January 2020. While in February 2020, average $\mathrm{SO}_{2}$ concentrations in Delhi, Mumbai, Kolkata, Chennai, and Hyderabad were $15,17,17,13$, and $7 \mu \mathrm{g} \mathrm{m}^{-3}$, respectively. Before the lockdown, average $\mathrm{SO}_{2}$ concentrations in Delhi, Mumbai, Kolkata, Chennai, and Hyderabad were 16, 18, 15, 9 , and $6 \mu \mathrm{g} \mathrm{m}^{-3}$, respectively. During the lockdown, average $\mathrm{SO}_{2}$ concentrations in Delhi, Mumbai, Kolkata, Chennai, and Hyderabad have reduced to $14,11,9,6$, and $6 \mu \mathrm{g} \mathrm{m}^{-3}$, respectively. The average $\mathrm{SO}_{2}$ concentrations were decreased by $12,39,40,33 \%$, and nil during the lockdown, in Delhi, Mumbai, Kolkata, Chennai, and Hyderabad, respectively, with those before the lockdown 
(Fig. 8(e1) and Table 1(e)). The average $\mathrm{SO}_{2}$ concentrations observed in April 2019 in Delhi, Mumbai, Kolkata, Chennai, and Hyderabad were 23, 31, 10, 7, and $6 \mu \mathrm{g} \mathrm{m}^{-3}$, respectively. When compared with average $\mathrm{SO}_{2}$ concentrations of the lockdown period in these cities with those observed in April 2019, it was found that average $\mathrm{SO}_{2}$ concentrations have decreased by 39,65 , 10, 14\%, and nil in Delhi, Mumbai, Kolkata, Chennai, and Hyderabad, respectively (Fig. 8(e2) and Table 1(e)).

The nationwide average $\mathrm{O}_{3}$ concentrations during January and February 2020 were 27 and $35 \mathrm{\mu g} \mathrm{m}^{-3}$, respectively. Whereas, the nationwide average $\mathrm{O}_{3}$ concentrations before the lockdown and during the lockdown were 36 and $39 \mu \mathrm{g} \mathrm{m}^{-3}$, respectively. The nationwide average $\mathrm{O}_{3}$ concentration was increased by $8 \%$ when compared with that before the lockdown period (Fig. 8(f1) and Table 1(f)). The nationwide average $\mathrm{O}_{3}$ concentration in April 2019 was $45 \mu \mathrm{g} \mathrm{m}^{-3}$. By comparing, the nationwide average $\mathrm{O}_{3}$ concentration of the lockdown period with that observed in April 2019, it has found decreased by 13\% ((Fig. 8(f2) and Table 1(f)). In Delhi, Mumbai, Kolkata, Chennai, and Hyderabad, the average $\mathrm{O}_{3}$ concentrations were 19, 37, 33, 31, and $29 \mu \mathrm{g} \mathrm{m}^{-3}$, respectively, in January 2020, and 31, 45, 39, 25, and $28 \mu \mathrm{g} \mathrm{m}^{-3}$, respectively, in February 2020. Before the lockdown, the average $\mathrm{O}_{3}$ concentrations in Delhi, Mumbai, Kolkata, Chennai, and Hyderabad were $35,34,42,39$, and $27 \mu \mathrm{g} \mathrm{m}^{-3}$, respectively. While during the lockdown, the average $\mathrm{O}_{3}$ concentrations in Delhi, Mumbai, Kolkata, Chennai, and Hyderabad were 43, 29, 47, 47 , and $29 \mathrm{~g} \mathrm{~m}^{-3}$, respectively. During the lockdown, the average $\mathrm{O}_{3}$ concentrations have increased by $23,12,21$, and $7 \%$ in Delhi, Kolkata, Chennai, and Hyderabad, respectively, with those before the lockdown (Fig. 8(f1) and Table 1(f)). Only in Mumbai, the average $\mathrm{O}_{3}$ concentration has decreased by $15 \%$ during the lockdown with that before the lockdown (Fig. 8(f1) and Table 1(f)). This may be due to a large decrease in $\mathrm{NO}_{2}$ concentration (74\%) in Mumbai during the lockdown (Fig. 8(d1) and Table 1(d)). The average $\mathrm{O}_{3}$ concentrations observed in April 2019 in Delhi, Mumbai, Kolkata, Chennai, and Hyderabad were $36,19,30,26$, and $42 \mu \mathrm{g} \mathrm{m}^{-3}$, respectively. When compared with the average $\mathrm{O}_{3}$ concentrations of the lockdown with those observed in April 2019 in Delhi, Mumbai, Kolkata, and Chennai, it was found that the average $\mathrm{O}_{3}$ concentrations of the lockdown were increased by $19,53,57$, and $81 \%$, respectively (Fig. 8(f2) and Table $1(\mathrm{f})$ ). It was observed that the formation of $\mathrm{O}_{3}$ in Mumbai, Kolkata, and Chennai was higher as compared to Delhi. This may be due to that Mumbai, Kolkata, and Chennai are coastal cities with a relatively clean environment and receives enough solar radiation, and probably have enough $\mathrm{O}_{3}$ precursors. However, a deeper investigation is needed to understand the reason for $\mathrm{O}_{3}$ formation in Mumbai, Kolkata, and Chennai and is beyond the scope of this study.

\subsection{Policy Relevance}

The COVID-19 has provided a rare opportunity to countries for the collection of air pollution baseline data since during the nationwide lockdown the emissions of air pollutants from transport, industries, and commercial activities were reduced significantly and have relevance to air pollution reduction policies. India imposed a nationwide lockdown from March 25, 2020, onward for a few months. As a result, the concentrations of air pollutants decreased significantly (Figs. 6 and 8). The observed nationwide average concentrations of $\mathrm{PM}_{10}$ and $\mathrm{PM}_{2.5}$ were well below the NAAQS of $\mathrm{PM}_{10}$ and $\mathrm{PM}_{2.5}$ during the nationwide lockdown (Figs. 6(a) and 6(b)). Also, the observed nationwide average concentrations of $\mathrm{NO}_{2}, \mathrm{SO}_{2}$, and $\mathrm{O}_{3}$ were always below the respective NAAQS of $\mathrm{NO}_{2}, \mathrm{SO}_{2}$, and $\mathrm{O}_{3}$ (Figs. 6(d), 6(e), and 6(f)). As per the WHO (2005) guidelines, the ambient air quality standards for $\mathrm{PM}_{10}$ and $\mathrm{PM}_{2.5}$ must be close to $50 \mu \mathrm{g} \mathrm{m}^{-3}$ and $25 \mu \mathrm{g} \mathrm{m}^{-3}$, respectively, considering their impacts on human health. The NAAQS of India for $\mathrm{PM}_{10}$ and $\mathrm{PM}_{2.5}$ is $100 \mu \mathrm{g} \mathrm{m}^{-3}$ and $60 \mu \mathrm{g} \mathrm{m}^{-3}$, respectively, which is about 2 times higher than the WHO (2005) prescribed guidelines. Considering the high pollution levels in India (WHO, 2016; Bernard and Kazmin, 2018; Chowdhury et al., 2019; HEI, 2019; Mishra, 2019), there is sufficient ground to review the current NAAQS of air pollutants for mitigation of air pollution. The air pollution measurement data summarized in this study showed that during the nationwide lockdown, emissions of air pollutants from transport, industries, and commercial activities were reduced significantly. As a result, the concentrations of $\mathrm{PM}_{10}$ and $\mathrm{PM}_{2.5}$ attained the NAAQS or even observed lower than the NAAQS. This suggests that if the emissions of air pollutants, particularly $\mathrm{PM}_{10}$ and $\mathrm{PM}_{2.5}$, reduced from transport, industries, commercial activities, including from biomass burning in 
domestic cooking as well open biomass burning, the current NAAQS, as well as the lower level of $\mathrm{PM}_{10}$ and $\mathrm{PM}_{2.5}$, can be achieved. This can be done by providing clean fuels and implementing 25 mitigations measures proposed by the Science-Based Solutions Report (UNEP, 2019).

\section{CONCLUSION}

This study made a detailed analysis of the impacts of the COVID-19 on air quality in India by using the observation data from more than 200 CAAQMS. India imposed a nationwide lockdown on March 25, 2020, for a few months and suspended transport, industries, and commercial activities, except for essential services. We defined the period from February 25 to March 24, 2020, as 'before lockdown' and March 25 to April 30, 2020, as 'during lockdown'. The study found that from January to April 2020, which included the nationwide lockdown period, the monthly NAQI was improved from poor to satisfactory or good; $A O D$ and emission hotspots of $C O, \mathrm{NO}_{2}$, and $\mathrm{SO}_{2}$ were gradually disappeared; and temporal variations in the concentrations $\mathrm{PM}_{10}, \mathrm{PM}_{2.5}$, $\mathrm{CO}, \mathrm{NO}_{2}$, and $\mathrm{SO}_{2}$ showed a gradually decreasing trend. The nationwide average concentrations of $\mathrm{PM}_{10}, \mathrm{PM}_{2.5}, \mathrm{CO}, \mathrm{NO}_{2}$, and $\mathrm{SO}_{2}$ decreased during the lockdown by $33,34,21,47$, and $21 \%$, respectively, compared to their levels before the lockdown. The average concentration levels of $\mathrm{PM}_{10}, \mathrm{PM}_{2.5}, \mathrm{CO}, \mathrm{NO}_{2}$, and $\mathrm{SO}_{2}$ of the lockdown period when compared with those observed in April 2019, it was found that their average concentration levels were decreased by 53, 45, 27, 54, and $35 \%$. The $\mathrm{O}_{3}$ level was slightly increased during the lockdown. The COVID-19 has provided a rare opportunity for India for the collection of air pollution baseline data which could be useful in the formulation of pollution reduction policies.

\section{ACKNOWLEDGMENT}

We would like to thank NASA's GIOVANNI for allowing us to plot visual maps of AOD, $\mathrm{NO}_{2}, \mathrm{CO}$, and $\mathrm{SO}_{2}$, and the $\mathrm{CPCB}$ for making available air quality data online. We are thankful to the Director and colleagues of the Regional Resource Centre for Asia and the Pacific (RRC.AP) for their encouragement and support. A special thanks to Ric Dennis A. Canullas of RRC.AP and Aurélia Lemoine (consultant at UNEP ROAP) for assisting us in finalizing the manuscript.

\section{REFERENCE}

Badarinath, K.V.S., Kharol, S.K., Sharma, A.R. (2009). Long-range transport of aerosols from agriculture crop residue burning in Indo-Gangetic Plains - A study using LIDAR, ground measurements and satellite data. J. Atmos. Sol. Terr. Phys. 71, 112-120. https://doi.org/10.10 16/j.jastp.2008.09.035

Baldasano, J.M. (2020). COVID-19 lockdown effects on air quality by $\mathrm{NO}_{2}$ in the cities of Barcelona and Madrid (Spain). Sci. Total Environ. 741, 140353. https://doi.org/10.1016/j.scitotenv.2020. 140353

Bauwens, M, Compernolle, S, Stavrakou, T, Müller, J.F., van Gent, J., Eskes, H., Levelt, P.F., van der A.R., Veefkind, J.P., Vlietinck, J., Yu, H., Zehner, C. (2020). Impact of coronavirus outbreak on $\mathrm{NO}_{2}$ pollution assessed using TROPOMI and OMI observations. Geophys. Res. Lett. 47, e2020G. https://doi.org/10.1029/2020GL087978

Berman, J.D., Ebisu, K. (2020). Changes in U.S. air pollution during the COVID-19 pandemic. Sci. Total Environ. 739, 139864. https://doi.org/10.1016/j.scitotenv.2020.139864

Bernard, S., Kazmin, A. (2018). Dirty air: How India became the most polluted country on earth. Financial Times. https://ig.ft.com/india-pollution/

Bhome, A.B. (2012). COPD in India: Iceberg or volcano? J. Thorac. Dis. 4, 298-309. https://doi.org/10.3978/j.issn.2072-1439.2012.03.15

Bray, C.D., Battye, W.H., Aneja, V.P. (2019). The role of biomass burning agricultural emissions in the Indo-Gangetic Plains on the air quality in New Delhi, India. Atmos. Environ. 218, 11698. https://doi.org/10.1016/j.atmosenv.2019.116983

Burnett, R., Chen, H., Szyszkowicz, M., Fann, N., Hubbell, B., Pope, C.A., Apte, J.S., Brauer, M., 
Cohen, A., Weichenthal, S., Coggins, J., Di, Q., Brunekreef, B., Frostad, J., Lim, S.S., Kan, H., Walker, K.D., Thurston, G.D., Hayes, R.B., Lim, C.C., ... Spadaro, J.V. (2018). Global estimates of mortality associated with long-term exposure to outdoor fine particulate matter. PNAS 115, 9592-9597. https://doi.org/10.1073/pnas.1803222115

Chowdhury, S., Dey, S., Guttikunda, S., Pillarisetti, A., Smith, K.R., Girolamo, L.D. (2019). Indian annual ambient air quality standard is achievable by completely mitigating emissions from household sources. PNAS Sci. 116, 10711-10716. https://doi.org/10.1073/pnas.1900888116

CPCB (2014). Report on National Air Quality Index (CUPS/82/2014-15). https://cpcb.nic.in /national-air-quality-index/

CPCB (2020). Impact of Lockdown (25th March To 15th April) on Air Quality. https://cpcb.nic.in/

Dekker, I.N., Houweling, S., Pandey, S., Krol, M., Röckmann, T., Borsdorff, T., Landgraf, J., Aben, I. (2019). What caused the extreme CO concentrations during the 2017 high-pollution episode in India? Atmos. Chem. Phys. 19, 3433-3445. https://doi.org/10.5194/acp-19-3433-2019

Gordon, T., Balakrishnan, K., Dey, S., Rajagopalan, S., Thornburg, J., Thurston, G., Agrawal, A., Collman, G., Guleria, R., Limaye, S., Salvi, S., Kilaru, V., Nadadur, S. (2019). Air pollution health research priorities for India: Perspectives of the Indo-U.S. Communities of Researchers, Environ. Int. 119, 100-108. https://doi.org/10.1016/j.envint.2018.06.013

Guttikunda, S.K., Goel, R., Pant, P. (2014). Nature of air pollution, emission sources, and management in the Indian cities. Atmos. Environ. 95, 501-510. https://doi.org/10.1016/j.atm osenv.2014.07.006

He, G., Pan, Y., Tanaka, T. (2020). The short-term impacts of COVID-19 lockdown on urban air pollution in China. Nat. Sustain. 3, 1005-1011. https://doi.org/10.1038/s41893-020-0581-y

HEI (2019). The Global Air 2019, Global exposure to air pollution and its disease burden. www.stateofglobalair.org

Jain, S., Sharma, T. (2020). Social and travel lockdown impact considering coronavirus disease (COVID-19) on air quality in megacities of India: Present benefits, future challenges and way forward. Aerosol Air Qual. Res. 20, 1222-1236. https://doi.org/10.4209/aaqr.2020.04.0171

Jat, R., Gurjar, B.R., Lowe, D. (2020). Regional pollution loading in winter months over India using high resolution WRF-Chem simulation. Atmos. Res. 249, 105326. https://doi.org/10.1016/j.at mosres.2020.105326

Kanawade, V.P., Srivastavab, A.K., Ram, K., Asmi, E., Vakkari, V., Son, V.K., Varaprasad, V., Sarangi, C. (2020). What caused severe air pollution episode of November 2016 in New Delhi? Atmos. Environ. 222, 117-125. https://doi.org/10.1016/j.atmosenv.2019.117125

Krishna, R.K., Ghude, S.D., Kumar, R., Beig, G., Kulkarni, R., Nivdange, S., Chate, D. (2019). Surface $\mathrm{PM}_{2.5}$ estimate using satellite-derived aerosol optical depth over India. Aerosol Air Qual. Res. 19, 25-37. https://doi.org/10.4209/aaqr.2017.12.0568

Kumar, S. (2020). Effect of meteorological parameters on spread of COVID-19 in India and air quality during lockdown. Sci. Total Environ. 745, 141021. https://doi.org/10.1016/j.scitotenv.2 020.141021

Kumari, K., Kumar, S., Rajagopal, V., Khare, A., Kumar, R. (2017). Emission from open burning of municipal solid waste in India. Environ. Technol. 40, 2201-2214. https://doi.org/10.1080/095 93330.2017.1351489

Kumari, P., Toshniwal, D. (2020). Impact of lockdown measures during COVID-19 on air qualityA case study of India, Int. J. Environ. Health Res. https://doi.org/10.1080/09603123.2020.177 8646

Kurokawa, J., Ohara, T. (2020). Long-term historical trends in air pollutant emissions in Asia: Regional Emission inventory in ASia (REAS) version 3.1. Atmos. Chem. Phys., 20, 12761-12793. https://doi.org/10.5194/acp-20-12761-2020

Liu, T., Marlier, M.E., DeFries, R.S., Westervelt, D.M., Xia, K.R., Fiore, A.M., Mickley, L.J., Cusworth, D.H., Milly, G. (2018). Seasonal impact of regional outdoor biomass burning on air pollution in three Indian cities: Delhi, Bengaluru, and Pune. Atmos. Environ. 172, 83-92. https://doi.org/1 0.1016/j.atmosenv.2017.10.024

Mahato, S., Pal, S., Ghosh, K.P. (2020). Effect of lockdown amid COVID-19 pandemic on air quality of the megacity Delhi, India. Sci. Total Environ. 730, 139086. https://doi.org/10.1016/j.scitote nv.2020.139086

Majumdar, D. (2021). How are the two most polluted metro-cities of India combating air 
pollution? Way forward after lifting of COVID-19 lockdown. Aerosol Air Qual. Res. 21, 200463. https://doi.org/10.4209/aaqr.2020.07.0463

Mishra, M. (2019). Poison in the air: Declining air quality in India. Lung India, 36, 160-161. http://www.lungindia.com/text.asp?2019/36/2/160/253180

Ojha, N., Sharma, A., Kumar, M., Girach, I., Ansari, T.U., Sharma, S.K., Singh, N., Pozzer, A., Gunthe, S.S. (2020). On the widespread enhancement in fine particulate matter across the Indo-Gangetic Plain towards winter. Sci. Rep. 10, 5862. https://doi.org/10.1038/s41598-02062710-8

Pallavi, Sinha, B., Sinha, V. (2019). Source apportionment of volatile organic compounds in the north-west Indo-Gangetic Plain using positive matrix factorisation model. Atmos. Chem. Phys. 19, 15467-15482. https://doi.org/10.5194/acp-19-15467-2019

Patel, K., Stevens, J. (2020). Airborne nitrogen dioxide plummets over China, NASA Earth Observatory. https://earthobservatory.nasa.gov

Rastogi, N., Singh, A., Sarin, M.M., Singh, D. (2016). Temporal variability of primary and secondary aerosols over northern India: Impact of biomass burning emissions. Atmos. Environ. 125, 396403. https://doi.org/10.1016/j.atmosenv.2015.06.010

Reddy, K.S., Roberts, J.H. (2019). The impact of air pollution on deaths, disease burden, and life expectancy across the states of India: The Global Burden of Disease Study 2017. Lancet Planet Health 3, e26-39. https://doi.org/10.1016/S2542-5196(18)30261-4

Rizwan, S.A., Nongkynrih, B., Gupta, S.K. (2013). Air pollution in Delhi: its magnitude and effects on health. Indian J. Community Med. 38, 4-8. https://doi.org/10.4103/09700218.106617

Sawlani, R., Agnihotri, R., Sharma, C., Patra, P.K., Dimri, A.P., Ram, K., Verma, R.L. (2019). The severe Delhi SMOG of 2016: A case of delayed crop residue burning, coincident firecracker emissions, and atypical meteorology. Atmos. Pollut. Res. 10, 868-879. https://doi.org/10.101 6/j.apr.2018.12.015

Sharma, S., Zhang, M., Anshika, Gao, J., Zhang, H., Kota, S.H. (2020). Effect of restricted emissions during COVID-19 on air quality in India, Sci. Total Environ. 728, 138878. https://doi.org/10.10 16/j.scitotenv.2020.138878

Shehzad, K., Sarfraz, M., Shah, S.G.M. (2020). The impact of COVID-19 as a necessary evil on air pollution in India during the lockdown. Environ. Pollut. 266, 115080. https://doi.org/10.1016/ j.envpol.2020.115080

Sicard, P, Marco, A.D., Agathokleous, E., Feng, Z.H., Xu, X., Paoletti, E., Rodriguez, J.J.D., Calatayud, V. (2020). Amplified ozone pollution in cities during the COVID-19 lockdown. Sci. Total Environ. 735, 139542. https://doi.org/10.1016/j.scitotenv.2020.139542

Singh, R.P., Chauhan, A. (2020). Impact of lockdown on air quality in India during COVID-19 pandemic. Air Qual. Atmos. Health 13, 921-928. https://doi.org/10.1007/s11869-020-00863-1

Sulaman, M, Long, X., Salman, M. (2020). COVID-19 pandemic and environmental pollution: A blessing in disguise? Sci. Total Environ. 728, 138820. https://doi.org/10.1016/j.scitotenv.2020. 138820

UNEP (2019). Air Pollution in Asia and the Pacific: Science-based Solutions. https://ccac oalition.org/en/resources/air-pollution-asia-and-pacific-science-based-solutions-summary-ful I-report\#

Wang, Q., Zeng, Q., Tao, J., Sun, L., Zhang, L., Gu, T., Wang, Z., Chen, L. (2019). Estimating PM2.5 concentrations based on MODIS AOD and NAQPMS data over Beijing-Tianjin-Hebei. Sensors 19, 1207. https://doi.org/10.3390/s19051207

WHO (2006). Air quality guidelines for particulate matter, ozone, nitrogen dioxide and sulfur dioxide: Global update 2005. https://apps.who.int/iris/handle/10665/69477

WHO (2016). Ambient air pollution: a global assessment of exposure and burden of disease. https://apps.who.int/iris/bitstream/handle/10665/250141/9789241511353-eng.pdf

Zhang, T., Zhu, Z., Gong, W., Zhu, Z., Sun, K., Wang, L., Huang, Y., Mao, F., Shen, H., Lig, Z., Xu, K. (2018). Estimation of ultrahigh resolution $\mathrm{PM}_{2.5}$ concentrations in urban areas using $160 \mathrm{~m}$ Gaofen-1 AOD retrievals. Remote Sens. Environ. 216, 91-104. https://doi.org/10.1016/j.rse.2 018.06.030 